\title{
Antifouling Compounds from Marine Invertebrates
}

\author{
Shu-Hua Qi * and Xuan Ma
}

Key Laboratory of Tropical Marine Bio-resources and Ecology, Guangdong Key Laboratory of Marine Materia Medica, RNAM Center for Marine Microbiology, South China Sea Institute of Oceanology,

Chinese Academy of Sciences, 164 West Xingang Road, Guangzhou 510301, China; mx20102112310039@126.com

* Correspondence: shuhuaqi@scsio.ac.cn; Tel.: +86-20-8902-2112; Fax: +86-20-8445-8964

Received: 30 April 2017; Accepted: 10 July 2017; Published: 28 August 2017

\begin{abstract}
In this review, a comprehensive overview about the antifouling compounds from marine invertebrates is described. In total, more than 198 antifouling compounds have been obtained from marine invertebrates, specifically, sponges, gorgonian and soft corals.
\end{abstract}

Keywords: marine invertebrate; sponge; coral; antifouling compound

\section{Introduction}

Biofouling includes microfouling (mainly by bacteria and diatoms) and macrofouling (by macro-algae and invertebrates) in the marine environment [1]. Biofouling is a thorny issue that brings tremendous losses in both marine technical and economic fields around the world. In past years, paints containing toxic materials like copper, lead, mercury, arsenic, and organotins such as tributyltin (TBT) were commonly used to control biofouling [2,3]. However, with the increasing global appeal for marine ecological protection, most of these toxic antifouling (AF) coatings were banned $[4,5]$. It is urgent to have environmentally benign, no or low-toxic AF agents. Marine natural small molecules were secondary metabolites of marine organisms, having the characteristics of high efficiency, low/non-toxicity, being easily degradable, and having less influence on the marine ecological environment, which are thought to be important channels for no or low-toxic AF agents.

Marine invertebrates have developed prominent chemical defense systems against biofouling in the course of evolution. Lots of AF compounds have been isolated from marine invertebrates. Several books [6,7] and reviews [2,8-14] on AF marine natural products, including compounds from marine invertebrates, have been published in the last 30 years. However, these reviews were partially about some representative AF compounds isolated from marine invertebrates over several years. The review contained in this paper covers almost all of the AF compounds from marine invertebrates from the last 30 years. Its aim is to give the readers a brief, yet comprehensive, overview of AF compounds from marine invertebrates and provide models for synthesis of more efficacious no or low-toxic antifoulants.

\section{Results}

Marine invertebrates, specifically, sponges, gorgonian and soft corals, are rich sources of novel and bioactive secondary metabolites. Studies of the natural chemistry of these interesting groups of marine invertebrates began in the late 1950s. They are recognized to mainly produce novel diterpenoids, sesquiterpenoids, prostanoids, alkaloids, and highly functionalized steroids that are largely unknown from terrestrial sources. Most of these compounds showed AF activity. 


\subsection{Terpenoids}

\subsubsection{Terpenoids from Sponges}

Terpenoids, especially isocyanoterpenoids, were the typical AF metabolites of marine sponges.

AF isocyanoterpenoids and analogues (Figure 1): Kalihinenes X-Z (1-3) [15] and kalihipyrans A-B (4-5) [16] were isolated from the marine sponge Acanthella cavernosa, showing strong AF activity towards Balanus amphitrite (=Amphibalanus amphitrite) larvae with $\mathrm{EC}_{50}$ values of $0.45-1.3 \mu \mathrm{g} / \mathrm{mL}$. Isocyanoterpenoids 15-formamidokalihinene (6) [16] and 10 $\beta$-formamidokalihinol A (7) [17] also obtained from $A$. cavernosa, inhibited the B. amphitrite larval settlement with $\mathrm{EC}_{50}<0.5 \mu \mathrm{g} / \mathrm{mL}$ and low toxicity $\left(\mathrm{LD}_{50} \mathrm{~s}>100 \mu \mathrm{g} / \mathrm{mL}\right)$. A similar AF activity was found for 10 -isocyano-4-cadinene (8) and isocyanotheonellin (9) that were isolated from nudibranchs of the family Phyllidiidae [18]. Kalihinols M-Q (10-15) and six analogues (16-21) were isolated from the Chinese marine sponge A. cavernosa, showing significant $\mathrm{AF}$ activity against $B$. amphitrite larvae with $\mathrm{EC}_{50}$ values of $0.27-1.85 \mu \mathrm{M}$ [19]. The diterpene isonitrile 22 isolated from Cymbastela hooperi, and the sesquiterpene axisonitrile-3 (23) isolated from Acanthella kletra, were effective in deterring the settlement of the diatom Nitzschia closterium [20]. Sesquiterpenes axinyssimides A-C (24-26) containing a rare dichloromethyleneamino functionality were isolated from a marine sponge Axinyssa sp. Among them, 24 inhibited the B. amphitrite larval settlement with $\mathrm{EC}_{50}$ value of $1.2 \mu \mathrm{g} / \mathrm{mL}$, and 25 and 26 were more active $\left(\mathrm{EC}_{50} \mathrm{~s}<0.5 \mu \mathrm{g} / \mathrm{mL}\right)$ [21].

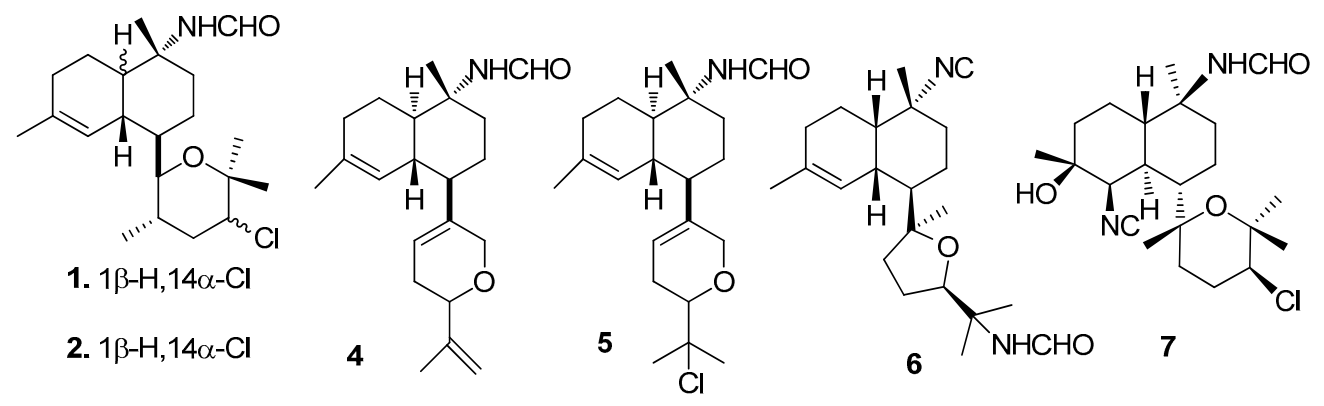

3. $1 \beta-\mathrm{H}, 14 \beta-\mathrm{Cl}$<smiles>CC1=C[C@H]2C(C(C)C)CC[C@H](C)[C@H]2CC1</smiles>

8<smiles>CC(=CC=CC(C)C)C1CCC(C)(N)CC1</smiles>

9

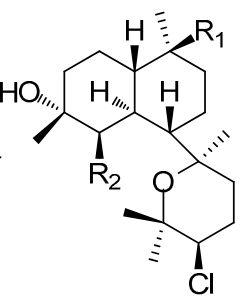

10. $R_{1}=N C S, R_{2}=N C$

12. $R_{1}=N C, R_{2}=N C S$

13. $R_{1}=N C S, R_{2}=N C S$

16. $R_{1}=N C, R_{2}=N C$

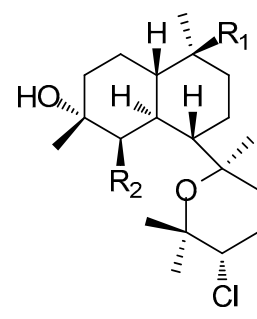

11. $R_{1}=N C, R_{2}=N C S$ 14. $R_{1}=N C S, R_{2}=N H C H O$

17. $R_{1}=N C, R_{2}=N C$

18. $R_{1}=N C S, R_{2}=N C$

19. $R_{1}=N C S, R_{2}=N C S$

20. $\mathrm{R}_{1}=\mathrm{NHCHO}, \mathrm{R}_{2}=\mathrm{NC}$

21. $R_{1}=N H C H O, R_{2}=N C S$
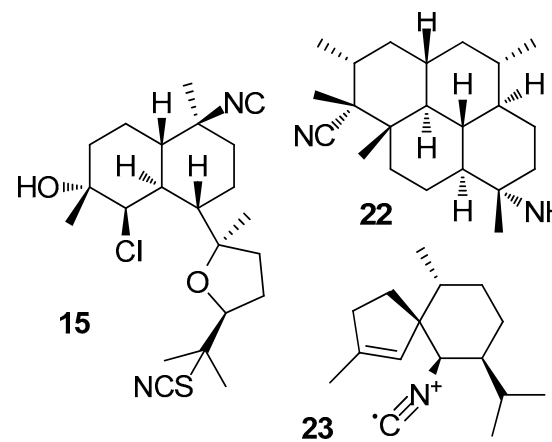

24

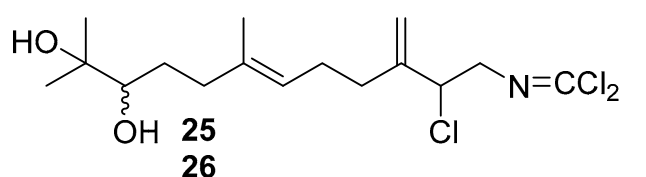

Figure 1. Structures of antifouling (AF) isocyanoterpenoids and analogues from sponges. 
Non-isocyanoterpenoids with AF activity from sponges (Figures 2 and 3) included sesquiterpenes, diterpenoids, sesterterpenes, and triterpenes. For examples:

Sesquiterpenes hydroquinone avarol (27) and avarone (28) obtained from the sponge Dysidea avara, and their synthetic analogs $3^{\prime}$-(p-chlorophenyl)avarone (29) and 4'-propylthioavarone (30) showed strong inhibition against B. amphitrite larvae with $\mathrm{EC}_{50}$ values of $0.45-3.41 \mu \mathrm{g} / \mathrm{mL}$ [22]. Sesquiterpenes, phenol derivatives (+)-curcuphenol (31) and (+)-curcudiol (32) from the sponge Myrmekioderma dendyi showed antilarval activity against $B$. amphitrite larvae at non-toxic concentrations with $\mathrm{EC}_{50}$ values of 2.5 and $2.8 \mu \mathrm{g} / \mathrm{mL}$, respectively [23].

Diterpenoid alkaloids (-)-agelasine D (33) and (-)-ageloxime D (34) from an Indonesian sponge Agelas sp. showed significant toxicity towards B. amphitrite larvae rather than just inhibiting settlement, and the toxicity of 34 was about 10 times than its congener 33, which indicated the importance of the oxime group for the activity of the diterpene alkaloids. Compound 33 also showed antibacterial activity against the planktonic form of Staphylococcus epidermidis (MIC $<0.0877 \mu \mathrm{M}$ ) but did not inhibit its biofilm formation [24].<smiles>[R]CC1(C)[C@H](C)CC[C@]2(C)C(C)=CCC[C@]12C</smiles>

27. $R=$<smiles>Cc1cc(O)ccc1O</smiles>

28. $R=$<smiles>O=C1C=CC(=O)C=C1</smiles>

29. $R=$-?<smiles>CC1=CC(=O)C=C(Nc2ccc(Cl)cc2)C1=O</smiles><smiles>CCCSC1=CC(=O)C(C=[Ru])=CC1=O</smiles><smiles>CC(C)=CCCC(C)c1ccc(C)cc1O</smiles><smiles>C=C1CC[C@]2(C)[C@@H](C)CCC[C@]2(C)[C@H]1CC/C(C)=C/Cn1c[n+](C)c2ncnc(N)c21</smiles><smiles>C=C1CC[C@@]2(C[C@]3(C)[C@H](C)CCC[C@@H]23)[C@@H](CC/C(C)=C(\C)C[n+]2cn(C)c3ncnc(NO)c32)C1</smiles>

Figure 2. Structures of AF sesquiterpenes and diterpenoids from sponges.

Sesterterpenes cavernosolide (35), lintenolide A (36) and 7E,12E,20Z-variabilin (37) isolated from the sponge Semitaspongia bactriana, showed strong toxicity against the diatom Nitzschia closterium and against Bugula neritina larvae with $\mathrm{EC}_{50}$ values from 1.22 to $7.41 \mu \mathrm{M}$ [25]. Two analogues of 37, dihydrofurospongin II (38) and hydroquinone-A acetate (39) obtained from multiple mediterranean sponge extracts showed significant $\mathrm{AF}$ activity against $B$. amphitrite larvae at nontoxic concentrations with $\mathrm{EC}_{50}$ values of about 2.5 and $1.0 \mu \mathrm{g} / \mathrm{mL}$, respectively [26].

Nortriterpenoids manoalide (40), seco-manoalide (41), manoalide 25-acetate (42) and $(4 E, 6 E)$-dehydromanoalide (43) from a sponge Smenospongia sp., strongly inhibited the B. amphitrite larval settlement at nontoxic concentrations with $\mathrm{EC}_{50}$ values of $0.24-2.7 \mu \mathrm{g} / \mathrm{mL}$ [24]. Compound 40 could also inhibit bacterial quorum sensing (QS) at low concentrations [27]. Formoside (44), a triterpene glycoside from the sponge Erylus formosus, could strongly deter the biofouling of invertebrates and algae [28]. 


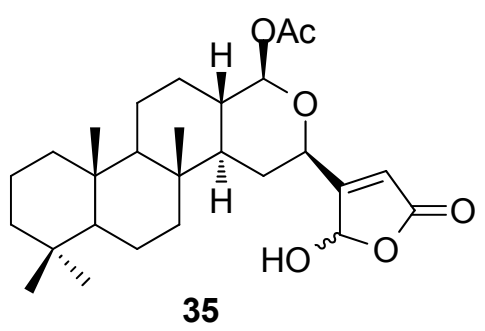<smiles>CC(=O)OCC12CC[C@H]3C4(C)CCC[C@H](C)[C@H]4CC[C@]3(C)[C@H]1CC(C1=CC(=O)O[C@@H]1O)O2</smiles>

36<smiles>[B]/C(=C\CCc1ccco1)CC/C=C(\C)CCCC(C)/C=C1\OC(=O)C(C)=C1O</smiles>

37<smiles>C/C(=C\CCc1ccoc1)CC(=O)C[C@H](C)CCCc1ccco1</smiles>

38<smiles>CC(=O)OCC(=CCCC(C)=CCc1cc(OC(C)=O)ccc1OC(C)=O)CCC=C(C)C</smiles><smiles>CC1=C(CC/C(C)=C/CC/C(C=O)=C\C[C@H](O)C2=CC(=O)OC2O)C(C)(C)CCC1</smiles>

40. $\mathrm{R}=\mathrm{H}$

41. $R=A C$

\section{3}

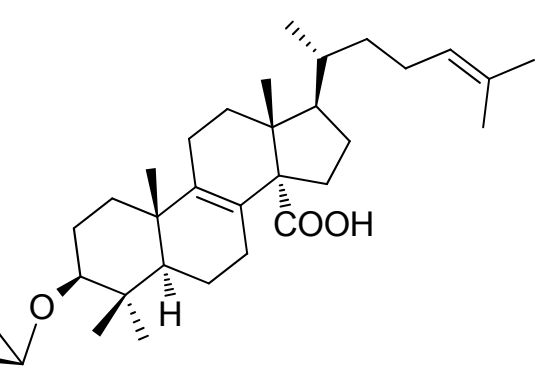<smiles>OCC1OC(O)C(O)C(O)C1O</smiles><smiles>COC(C)C(C)CCO</smiles><smiles>OCCOC1OCCO1</smiles>

44

Figure 3. Structures of sesterterpenes and triterpenes from sponges.

\subsubsection{Terpenoids from Corals}

The principal terpenoids elaborated by gorgonian and soft corals are sesquiterpenes and diterpenes. The representative structures of diterpenoids by carbon skeleton class from corals included briarane type, cembrane type, eunicellan type, xenicane type, pseudopterosin type, dilophol type, etc. Many of these diterpenoids were reported to have AF activity against marine invertebrate larvae.

AF sesquiterpenoids (Figure 4): Guaiazulene-based terpenoids anthogorgiene G (45) and analogus 46-48 were isolated from a gorgonian Anthogorgia sp., showing inhibition against the larval settlement of $B$. amphitrite larvae with $\mathrm{EC}_{50}<7.0 \mu \mathrm{g} / \mathrm{mL}$ [29]. (+)-(7R,10S)-2-methoxy,5-acetoxy calamenene (49) obtained from the octocorals of Indian waters exhibited AF activity against $B$. amphitrite with $\mathrm{EC}_{50}$ value of $0.0335 \mu \mathrm{g} / \mathrm{mL}$ [30]. Subergorgic acid (50) obtained from the gorgonian Subergorgia suberosa showed inhibition against the larval settlement of both B. amphitrite and B. neritina larvae with $\mathrm{EC}_{50}$ values of 1.2 and $3.2 \mu \mathrm{g} / \mathrm{mL}$, respectively [31]. Sinularones A-B (51-52) from a soft coral Sinularia sp. showed medium AF activity against $B$. amphitrite larvae [32]. 
<smiles></smiles>

46<smiles></smiles>

47<smiles>Cc1ccc2c(C)cc(C(C)C)c(-c3cc(C(C)C)ccc3C)c2c1</smiles>

48<smiles>COc1cc(C)c(OC(C)=O)c2c1[C@H](C)CC[C@H]2C(C)C</smiles>

49

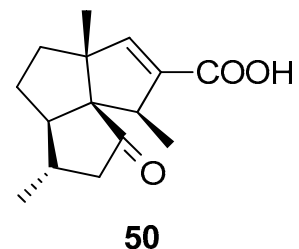

50<smiles>CC(=O)CC/C=C(/C)C[C@H]1CC(C)(C)CC1=O</smiles>

51<smiles>CCCCC[C@]1(O)C(C)=C(C)C(=O)[C@H]1CC(=O)OCC</smiles>

52

Figure 4. Structures of AF sesquiterpenoids from corals.

AF briarane-type diterpenoids (Figure 5): Junceellolide (53) and praelolide (54) isolated from the gorgonian Dichotella gemmacea, showed medium AF activity against the settlement of B. amphitrite larvae [33]. Dichotellides H, I, K-P, U (55-63) and junceellolide C (64) were also isolated from D. gemmacea, showing potent $\mathrm{AF}$ activity at nontoxic concentrations with $\mathrm{EC}_{50}$ values of $0.2-7.6 \mu \mathrm{g} / \mathrm{mL}$ [34]. Juncins R-ZI (65-74), juncin ZII (75), gemmacolide B (76), gemmacolide A (77) and junceellolide D (78) were isolated from the gorgonian Junceella juncea, showing potent $\mathrm{AF}$ activity against $B$. amphitrite larvae at nontoxic concentrations with $\mathrm{EC}_{50}$ values from 0.004 to $21.06 \mu \mathrm{g} / \mathrm{mL}[35,36]$. Briaranes (+)-junceellolide A (79), fragilisinins E (80), F (81) and J (82) from $J$. fragilis showed AF activity against $B$. amphitrite larvae with $\mathrm{EC}_{50}$ values of 5.6-14.0 $\mu \mathrm{M}$ and low toxicity [37]. Reticulolide (83) obtained from the gorgonian $S$. mollis showed strong inhibition against the larval settlement of $B$. amphitrite larvae with $\mathrm{EC}_{50}$ value of $0.35 \mu \mathrm{g} / \mathrm{mL}$ [38].

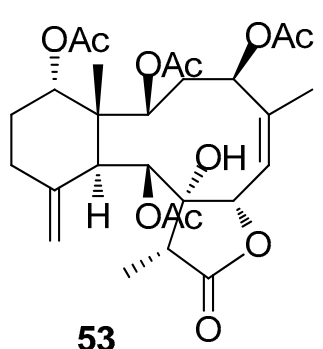

53

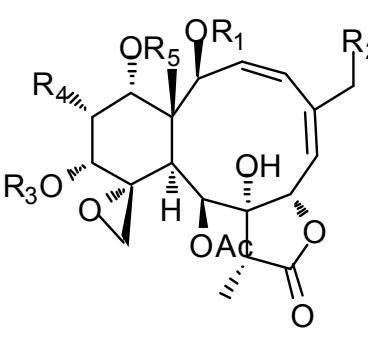

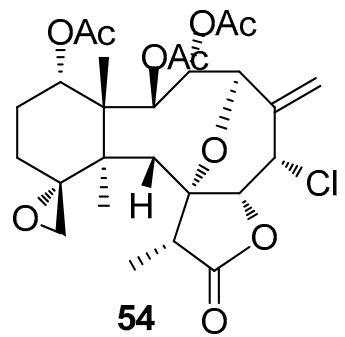

55. $R=Y, R_{2}=C l, R_{3}=X, R_{4}=O A c, R_{5}=A c$ 56. $R=A c, R_{2}=O X, R_{3}=A c, R_{4}=O A c, R_{5}=A c$ 57. $R=A c, R_{2}=O X, R_{3}=A c, R_{4}=O X, R_{5}=A c$ 58. $R=A c, R_{2}=O X, R_{3}=A c, R_{4}=O A c, R_{5}=X$

59. $R=A c R_{2}=O C H_{3}, R_{3}=X, R_{4}=O X, R_{5}=A c$

60. $R=A c, R_{2}=O C H_{3}, R_{3}=A c, R_{4}=H, R_{5}=X$

61. $R=A c, R_{2}=O C H_{3}, R_{3}=X, R_{4}=H, R_{5}=A c$ 62. $R=A c, R_{2}=O X, R_{3}=A c, R_{4}=H, R_{5}=X$<smiles>[Y]C(=O)CC(C)C</smiles><smiles>[Y]=CC(=O)COC(=O)CC(C)C</smiles>

Figure 5. Cont.

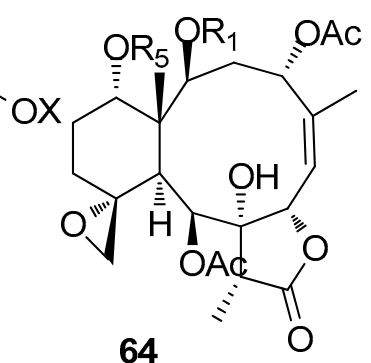

64

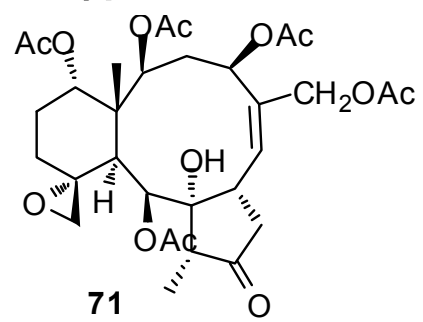




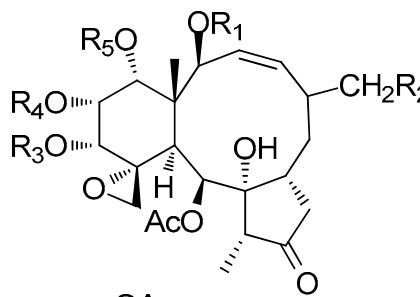

65. $\mathrm{R}_{1}=\mathrm{R}_{3}=\mathrm{R}_{4}=\mathrm{Ac}, \mathrm{R}_{2}=\mathrm{Cl}, \mathrm{R}_{5}=\mathrm{C}_{4} \mathrm{H}_{9} \mathrm{CO}$

66. $R_{1}=R_{4}=R_{5}=A c, R_{2}=C l, R_{3}=C_{4} H_{9} C O$

67. $\mathrm{R}_{1}=\left(\mathrm{CH}_{3}\right)_{2} \mathrm{CHCH}_{2} \mathrm{CH}_{2} \mathrm{COOCH}_{2} \mathrm{CO}$

$\mathrm{R}_{2}=\mathrm{OH}, \mathrm{R}_{3}=\mathrm{R}_{4}=\mathrm{R}_{5}=\mathrm{Ac}$

68. $R_{1}=R_{3}=R_{5}=A c, R_{2}=O_{3} H_{3}, R_{4}=C_{4} H_{9} C O$

69. $R_{1}=R_{4}=A c, R_{2}=O C H_{3}, R_{3}=R_{5}=H$

70. $R_{1}=R_{4}=A c, R_{2}=O A c, R_{3}=R_{5}=H$

O

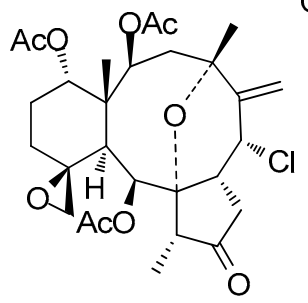

74

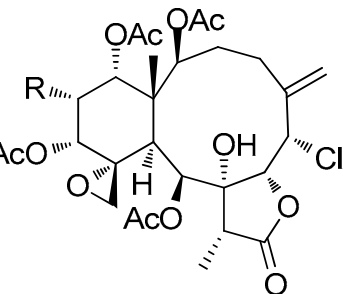

75. $\mathrm{R}=\mathrm{OCO}\left(\mathrm{CH}_{2}\right)_{2} \mathrm{CH}\left(\mathrm{CH}_{3}\right)_{2}$

76. $\mathrm{R}=\mathrm{OCOCH}_{2} \mathrm{CH}\left(\mathrm{CH}_{3}\right)_{2}$

77. $\mathrm{R}=\mathrm{OAC}$

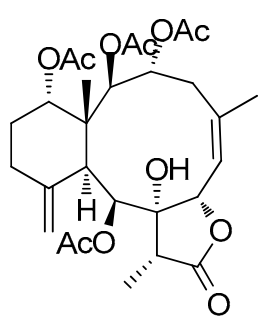

78

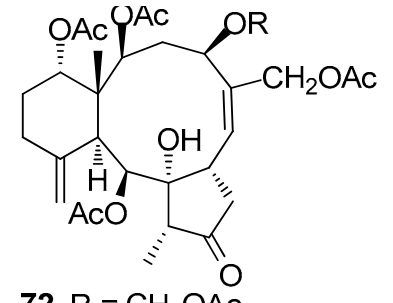

72. $\mathrm{R}=\mathrm{CH}_{2} \mathrm{OAC}$

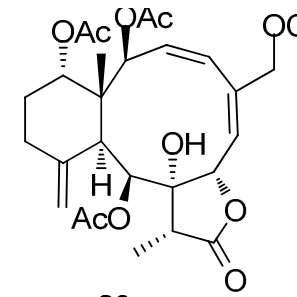

80

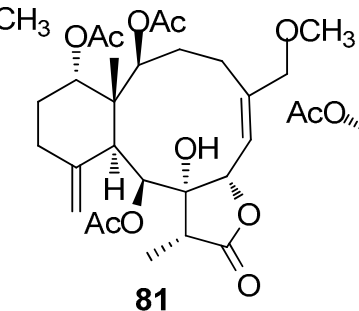

81

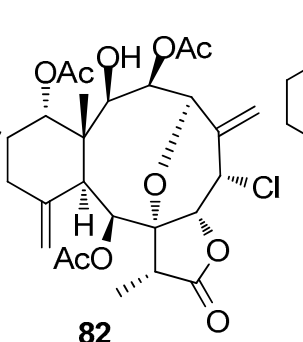

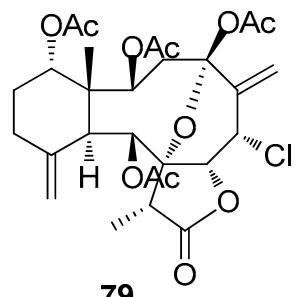

79

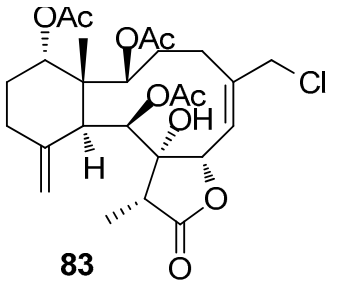

Figure 5. Structures of AF briarane-type diterpenoids from corals.

AF eunicellin-based diterpenoids (Figure 6): 14-Deacetoxycalicophirin B (84), astrogorgins B-D (85-87), and analogues 88-89 isolated from a gorgonian Astrogorgia sp., exhibited AF activity against B. amphitrite larvae with $\mathrm{EC}_{50}$ values of $0.59-17.8 \mu \mathrm{g} / \mathrm{mL}$ [39]. (-)-6 $\alpha$-Hydroxypolyanthelline $\mathrm{A}(\mathbf{9 0})$ from the soft coral Cladiella krempfi showed toxicity and AF activity against B. amphitrite larvae [40].

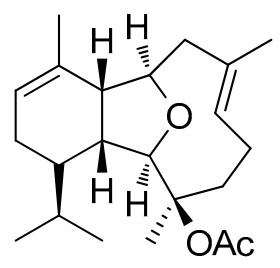

84

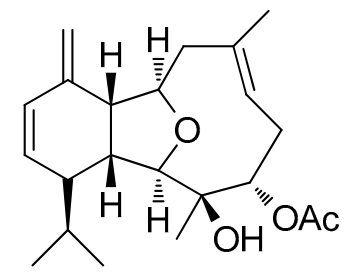

88<smiles>CC(=O)O[C@H]1C=C(C)[C@H]2[C@@H](C/C(C)=C/C[C@H](OC(C)=O)[C@@H](C(C)(C)O)[C@@H]2C(C)(C)O)O1</smiles>

85

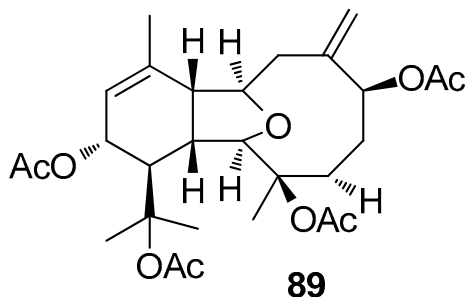

89

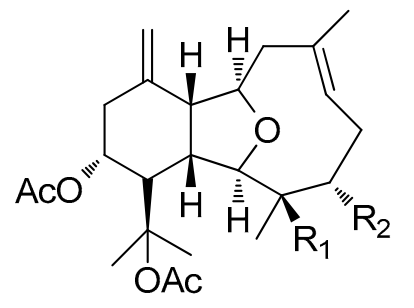

86. $\mathrm{R}_{1}=\mathrm{OH}, \mathrm{R}_{2}=\mathrm{OAC}$

87. $R_{1}=O A c, R_{2}=H$

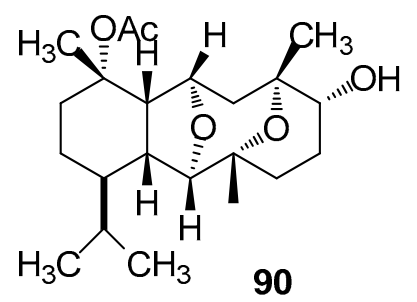

Figure 6. Structures of AF eunicellin-based diterpenoids from corals. 
AF cembrane-type diterpenoids (Figure 7): Pukalide (91) from the gorgonian Leptogorgia virgulata showed strong inhibition against the larval settlement of $B$. amphitrite larvae with $\mathrm{EC}_{50}$ value of $19 \mathrm{ng} / \mathrm{mL}$ [41]. Cembranoid epimers 92-95 isolated from the Colombian Caribbean gorgonian Pseudoplexaura flagellosa, could inhibit the biofilm maturation of Pseudomonas aeruginosa, Vibrio harveyi, and Staphylococcus aureus without interfering the bacterial growths [42]. Knightine (96), 11(R)-hydroxy-12(20)-en-knightal (97), and 11(R)-hydroxy-12(20)-en-knightol acetate (98) from the gorgonian Eunicea knighti, disrupted QS systems and showed anti-film activity against the bacterial biofilm of P. aeruginosa, $V$. harveyi, and S. aureus at lower concentrations than kojic acid [43]. Sinulariols $\mathrm{J}$ (99), P (100), Y (101) and its analogue 102 from the soft coral Sinularia rigida showed potent AF activity against the larval settlement of $B$. amphitrite and B. neritina larvae with $\mathrm{EC}_{50}<14.03 \mu \mathrm{g} / \mathrm{mL}[44,45]$. Pavidolides C-D (103-104) from the soft coral S. pavida exhibited inhibition against the larval settlement of $B$. amphitrite larvae with $\mathrm{ED}_{50}$ values of 4.32 and $2.12 \mu \mathrm{g} / \mathrm{mL}$ and low cytotoxicity $\left(\mathrm{LD}_{50}>50 \mu \mathrm{g} / \mathrm{mL}\right)$ [46]. Four cembrene diterpenoids 105-108 from the soft coral Sarcophyton infundibuliforme showed significant inhibition against the settlement of $B$. amphitrite larvae at nontoxic concentrations [47].

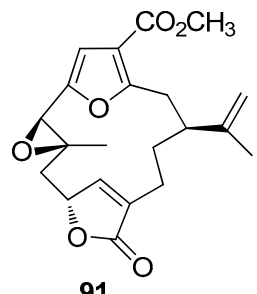

91<smiles>C=C(C)[C@H]1CC[C@@H](C)C(=O)CCC(=O)C(C)CC(=O)CC(C)C1</smiles>

95

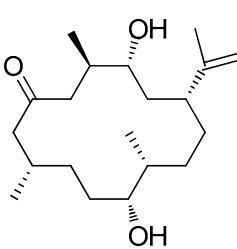

92

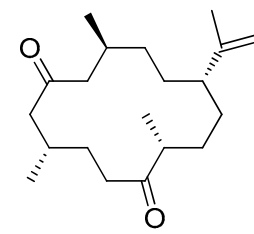

93

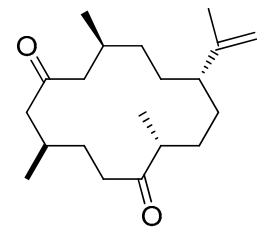

94<smiles>CC(=CCC[C@@H](O)CC=C(C(C)C)C1C[C@@](C)(O)C[C@@H](C)O1)CO</smiles>

99<smiles>C=C(CO)CC/C=C(\C)CCC1OC1(C)CC/C(=C/C(C)C(C)C)C(C)C</smiles>

96

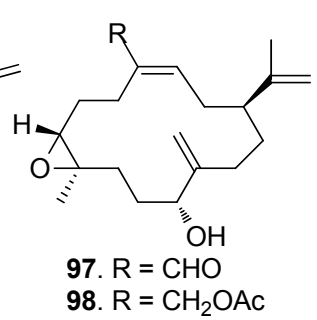

98. $\mathrm{R}=\mathrm{CH}_{2} \mathrm{OAC}$

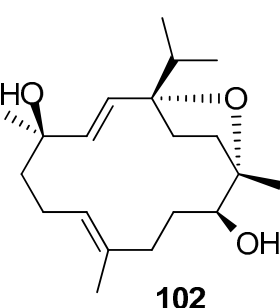

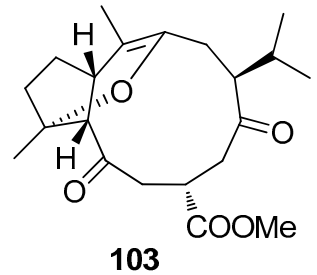<smiles>C/C1=C\CC[C@H](C)[C@@H]2CC[C@@](C)(O)[C@@H]2/C=C(/C(C)C)CC1</smiles>

104
101
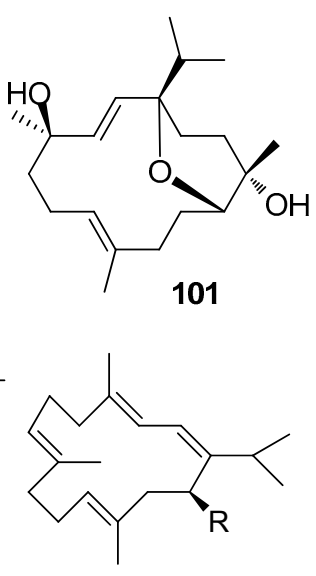

105. $\mathrm{R}=\mathrm{OH}$ 106. $R=O A C$

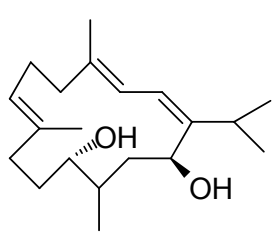

107

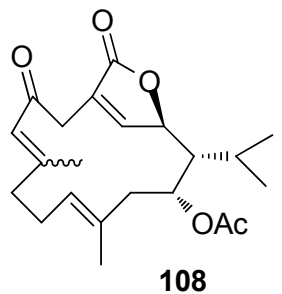

108

Figure 7. Structures of AF cembrane-type diterpenoids from corals.

\subsubsection{Terpenoids from Other Marine Invertebrates}

Briarane-type diterpenoids renillafoulins A (109) (Figure 8), B, and C from the sea pen Renilla reniformis showed strong inhibition against the barnacle settlement with $\mathrm{EC}_{50}$ values ranging $0.02-0.2 \mu \mathrm{g} / \mathrm{mL}[48,49]$. A labdane diterpene $\mathbf{1 1 0}$ from the pulmonate limpet Trimusculus reticulatus 
could inhibit the settlement of Phragmatopoma californica larvae at $10 \mu \mathrm{g} / \mathrm{mL}$, and its lethal concentration to the larvae was $100 \mu \mathrm{g} / \mathrm{mL}$ [50].

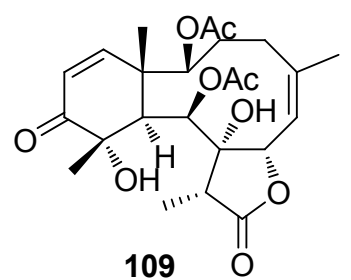<smiles>CC1=C(CC/C(C)=C/CO)[C@]2(C)CCCC(C)(C)[C@H]2[C@H](OC(=O)CC(C)C)C(O)C1C</smiles>

Figure 8. Structures of AF terpenoids from other marine invertebrates.

\subsection{Steroids and Saponins}

\subsubsection{Steroids from Sponges}

Two steroids tri-2-aminoimidazolium halistanol sulfate (111) and halistanol sulfate (112) (Figure 9) from a marine sponge Topsentia sp, showed AF activity but no toxicity against B. amphitrite larvae with $\mathrm{EC}_{50}$ values of 4.0 and $2.9 \mu \mathrm{g} / \mathrm{mL}$, respectively [23]. Three new A-nor steroids, the ethyl esters of $2 \beta$-hydroxy-4,7-diketo-A-norcholest-5-en-2-oic acid (113), 24S-ethyl$2 \beta$-hydroxy-4,7-diketo-A-norcholest-5-en-2-oic acid (114), and $2 \beta$-hydroxy-4,7-diketo-24R-methylA-norcholest-5,22(E)-dien-2-oic acid (115) from the Chinese marine sponge Acanthella cavernosa showed medium AF activity against B. albicostatus larvae [51]. Cyclopropanated sterols aragusterol I (116) and 21-O-octadecanoyl-xestokerol A (117) isolated from the sponge Xestospongia testudinaria, inhibited the growth of Pseudoalteromonas and Polaribacter bacterial species at similar levels of activity to the positive control tributyltin oxide [52].

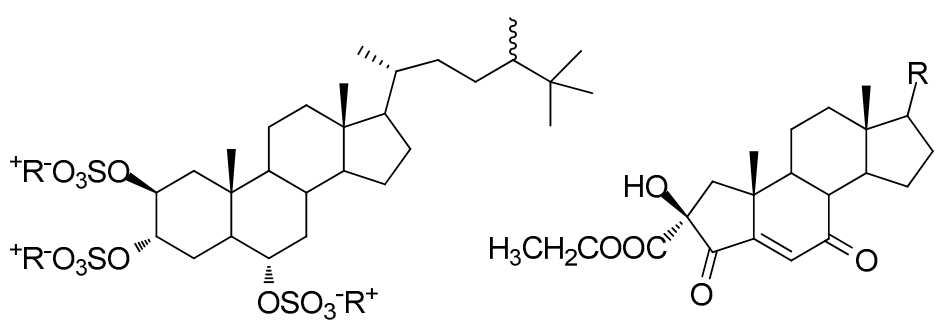

113. $R=$<smiles>[R]CC(C)CCCC(C)C</smiles><smiles>NC1=[14CH][R]C=CN1</smiles>

112. $\mathrm{R}^{+}=\mathrm{Na}^{+}$

115. $R$

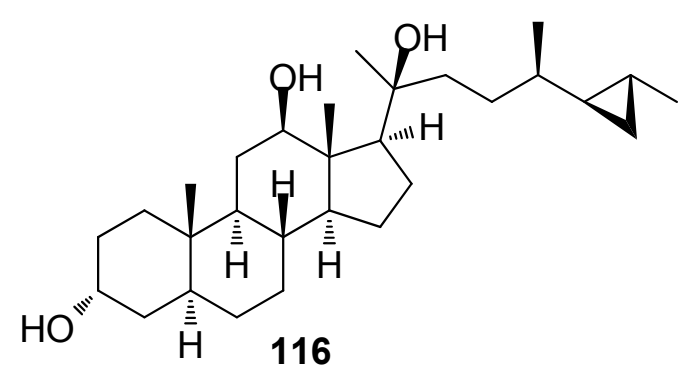

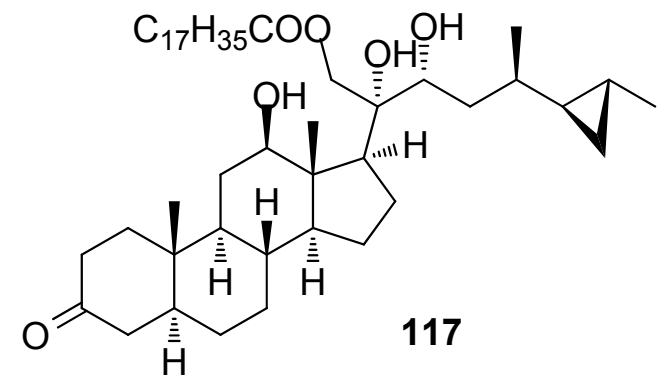

Figure 9. Structures of AF steroids from sponges. 


\subsubsection{Steroids from Coals}

Steroids 118 and 119 (Figure 10) from the gorgonian S. suberosa inhibited the settlement of B. neritina larvae with $\mathrm{EC}_{50}$ values of 6.25 and $7.8 \mu \mathrm{g} / \mathrm{mL}$, respectively, and $\mathrm{LD}_{50}>250 \mu \mathrm{g} / \mathrm{mL}$ [53]. Compound $\mathbf{1 2 0}$ was a 5a-hydroxylated analog of $\mathbf{1 1 5}$, having similar AF activity against $B$. neritina larvae and $B$. amphitrite larvae [51]. $1 \alpha, 3 \beta, 7 \alpha, 11 \alpha, 12 \beta)$-Gorgost-5-ene-1,3,7,11,12-pentol 12-acetate (121) from the gorgonian Isis minorgrachyblasta inhibited the settlement of B. neritina larvae with $\mathrm{EC}_{50}$ value of $4.8 \mu \mathrm{g} / \mathrm{mL}$ and $\mathrm{LC}_{50}>100 \mu \mathrm{g} / \mathrm{mL}$ [54]. Four 24-ketal steroids (122-125) from the gorgonian $S$. mollis showed $\mathrm{AF}$ activity against $B$. amphitrite larvae at nontoxic concentrations with $\mathrm{EC}_{50}$ values of $0.81-7.91 \mu \mathrm{g} / \mathrm{mL}$ [39]. Pregn-4-ene-3,20-dione (126) showed medium AF activity against the larval settlement of both B. amphitrite and B. neritina larvae [31]. A pentacyclic hemiacetal sterol nephthoacetal (127) from a soft coral Nephthea sp. showed significant AF activity against B. amphitrite larvae with $\mathrm{EC}_{50}$ value of $2.5 \mu \mathrm{g} / \mathrm{mL}$ and $\mathrm{LC}_{50}>25.0 \mu \mathrm{g} / \mathrm{mL}$ [55]. Two cholestane derivatives, pentacyclic steroid 16,22-epoxy-20 $\beta, 23 S$-dihydroxycholest-1-ene-3-one (128) and 20 $\beta$, 23S-dihydroxycholest-1-ene-3,22-dione (129) from the gorgonian S. suberosa showed potent inhibition activity towards the settlement of $B$. amphitrite larvae [56]. Unprecedented D-secosteroids, isogosterones A (130) and C (131) isolated from a soft coral Dendronephthya sp. exhibited AF activity against B. amphitrite larvae with $\mathrm{EC}_{50}$ value of $2.2 \mu \mathrm{g} / \mathrm{mL}$. 9,10-Secosteroids (132-133) from the gorgonian Muricella sibogae showed medium inhibition against the settlement of B. amphitrite larvae [57].

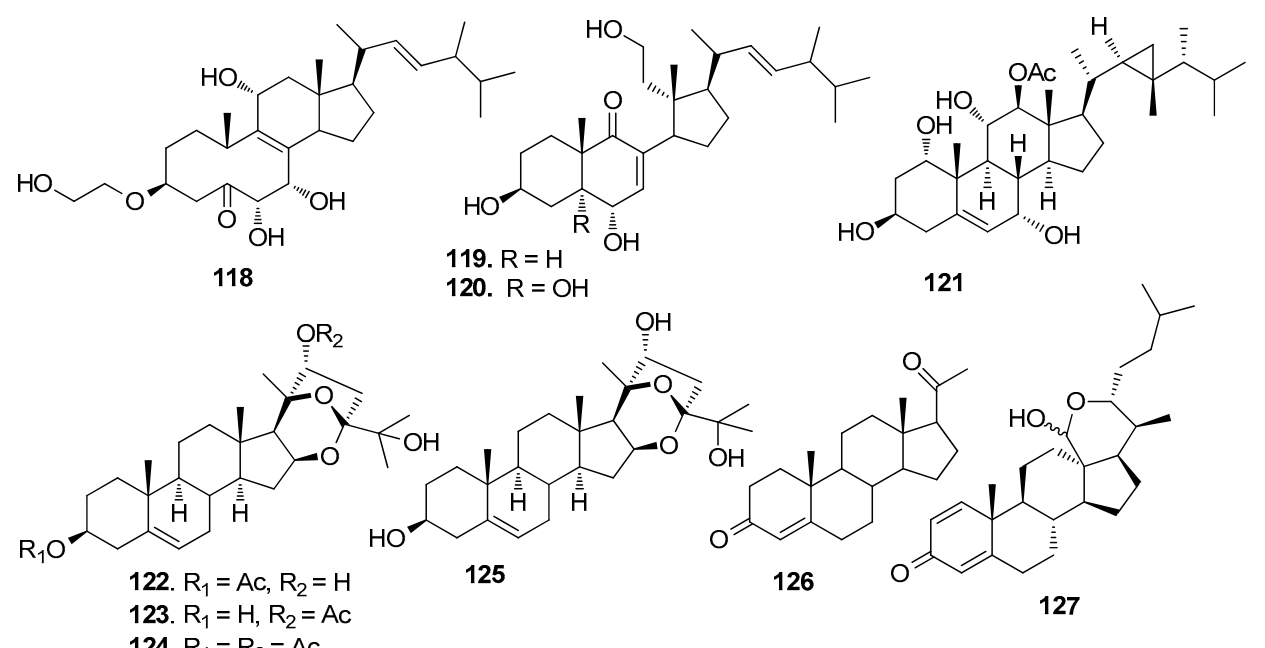

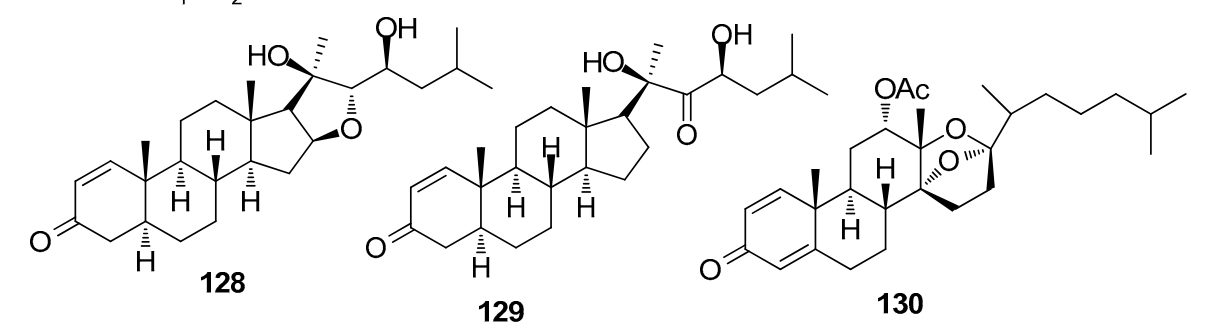<smiles>CC(C)CCC(=O)C(C)C1(O)CCC2(O1)C1CCC3=CC(=O)C=CC31CCC(O)C2(C)O</smiles>

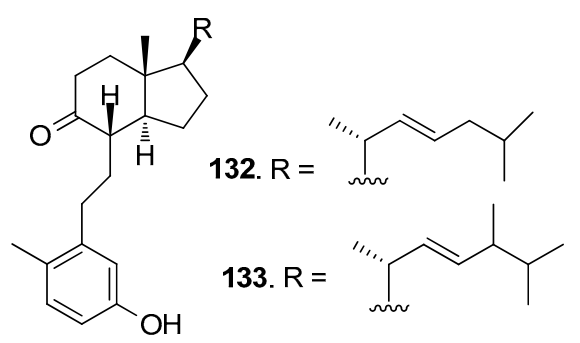

Figure 10. Structures of AF steroids from corals. 


\subsection{Alkaloids}

Many types of AF alkaloids, especially brominated alkaloids, have been isolated from marine sponges.

AF bromotyrosine-derived compounds (Figure 11): Bromotyrosine-derived compounds were specially found in marine sponges of the families Aplysinidae and Pseudoceratinidae, particularly Pseudoceratina (=Psammaplysilla) purpurea. Ceratinamine (134) [58], moloka'iamine (135) [59], ceratinamides A-B (136-137) [58], and psammaplysins A (138) and E (139) [58] were isolated from the sponge $P$. purpurea, showing $\mathrm{AF}$ activity against $B$. amphitrite cyprids with $\mathrm{EC}_{50}$ values ranging from 0.10 to $8.0 \mu \mathrm{g} / \mathrm{mL}$ [58]. The AF activities of aplysamine-2 (140) from P. purpurea, a synthetized analog hemibastadin-1 (141), psammaplins A (142) from Aplysinella rhaxand, and three bastadins-9, $-16,-3(\mathbf{1 4 3}-145)$ derivatives from Ianthella basta were also evaluated. Among them, 140 and 143-145 could significantly inhibit the settlement of $B$. amphitrite larvae at concentrations of 1 or $10 \mu \mathrm{M}$ without increasing larval mortality, while 141, 142 and 144 showed inhibition against larval settlement at $10 \mu \mathrm{M}$ with significant mortality of the cyprids [60].

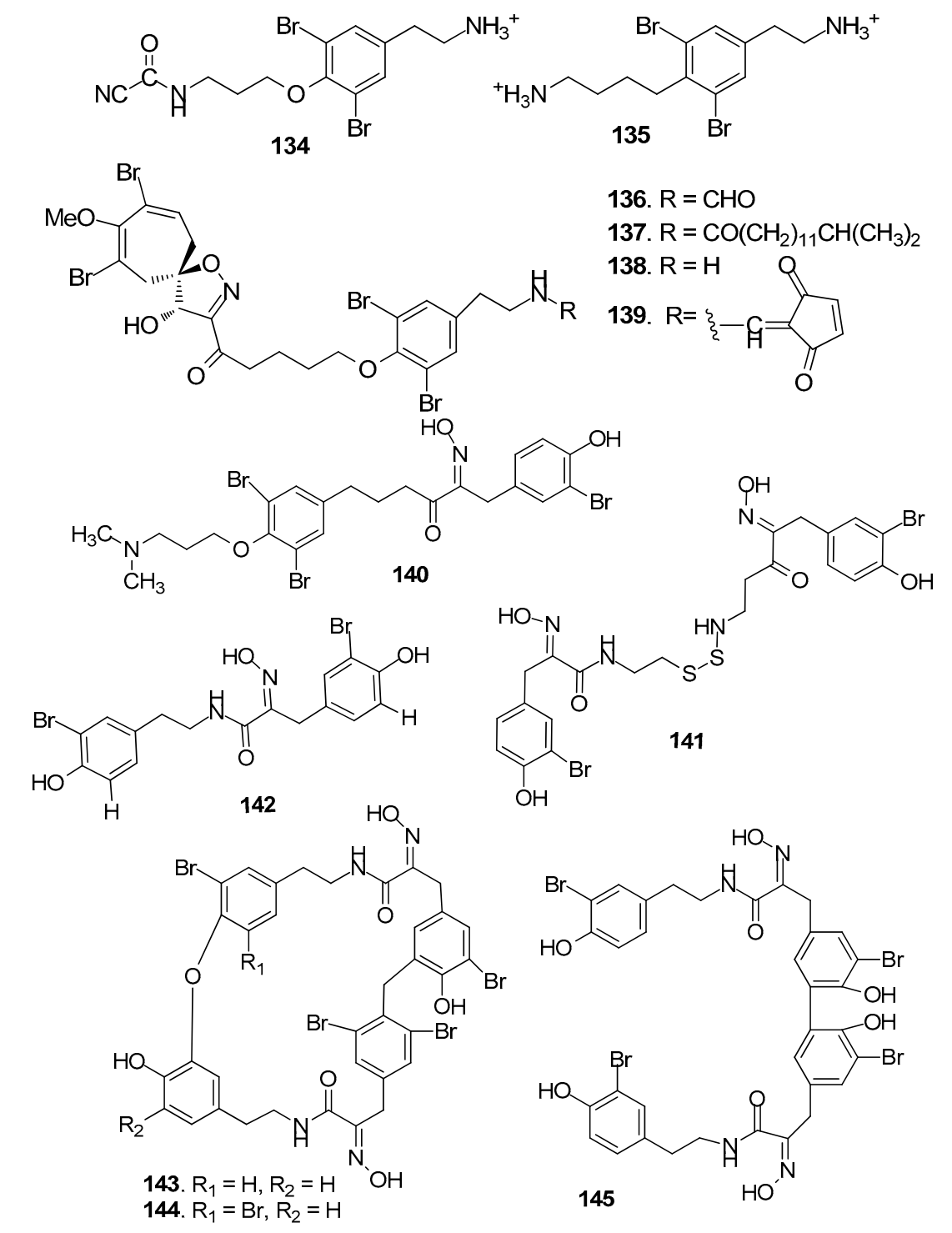

Figure 11. Structures of AF bromotyrosine-derived compounds from sponges. 
AF pyrrole-derived compounds (Figure 12): Bromopyrrole-derived compounds 4,5-dibromopyrrole2-carbamide (146), oroidin (147) and mauritiamine (148) were isolated from the sponge Agelas mauritiana. Compounds 147 and 148 showed medium inhibition against the larval metamorphosis of $B$. amphitrite larvae, while 146 could promote the larval metamorphosis of the ascidian Ciona savignyi at $2.5 \mu \mathrm{g} / \mathrm{mL}$ [61]. A spermidine derivative pseudoceratidine (149) from P. purpurea showed AF activity against B. amphitrite larvae [62]. Hymenialdisine (150) and debromohymenialdisine (151) isolated from a sponge Axinella sp. were found to exhibit significant AF activity against the green mussel Perna viridis, the bryozoan B. neritina, and the green alga Ulva. prolifera [63]. A pyrroloimidazole alkaloid $\mathbf{1 5 2}$ isolated from sponge, showed significant inhibition against the bacterial attachment of Pseudomonas with $\mathrm{IC}_{50}$ value of $0.73 \mu \mathrm{M}$ [64].<smiles>[Y2]CNC(=O)CCCc1c[nH]c(N)n1</smiles>

Figure 12. Structures of AF pyrrole-derived compounds from sponges.

AF pyridine-derived compounds (Figure 13): Two synthetic compounds haminol-A (153) and haminol-B (154), and three natural compounds haminol-2 (155), haminol-4 (156) and saraine-1 (157) from Haliclona fusari were evaluated for their AF activity, which showed that 153-157 significantly inhibited the larval settlement of $B$. amphitrite larvae with $\mathrm{EC}_{50}$ values ranging from 0.28 to $3.6 \mu \mathrm{g} / \mathrm{mL}[65]$.

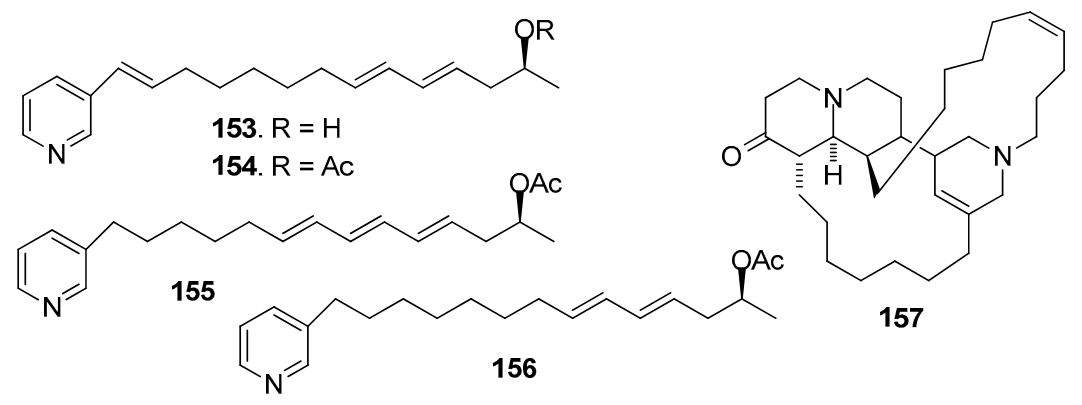

Figure 13. Structures of AF pyridine-derived compounds from sponges.

AF indole alkaloids (Figure 14): Alkaloids 2-bromo- $N$-methyltryptamine 158-159 from the gorgonian Paramuricea clavata showed significant anti-adhesion activity against one marine bacterial strain with nontoxicity [66]. Barettin (160) and 8,9-dihydrobarettin (161) from the sponge Geodia barretti showed inhibition against the settlement of $B$. improvises larvae with $\mathrm{EC}_{50}$ values of 0.9 and $7.9 \mu \mathrm{M}$, respectively [67]. In 2006, 14 analogs of $\mathbf{1 6 1}$ were synthesized. Among them, benzo[ $g$ ]dipodazine (162) and other four dipodazine analogs (163-166) with a dipodazine group significantly inhibited the settlement of $B$. improvisus larvae with $\mathrm{EC}_{50}$ values of $0.034,5.8,1.5,2.4$ and $6.7 \mu \mathrm{M}$ [68], 
respectively. Bromobenzisoxazolone barettin (167) from the sponge G. barrette inhibited the settlement of B. improvisus larvae with $\mathrm{EC}_{50}$ value of $15 \mathrm{nM}$ [69].<smiles>[R]c1[nH]c2cc([R])c3ccc(Br)cc3c2c1CCN([R6])[R]</smiles>

158. $R_{1}=R_{2}=R_{4}=H, R_{3}=B r, R_{5}=C_{3}$ 159. $R_{1}=O H, R_{2}=R_{3}=H, R_{4}=R_{5}=C_{3}$<smiles></smiles>

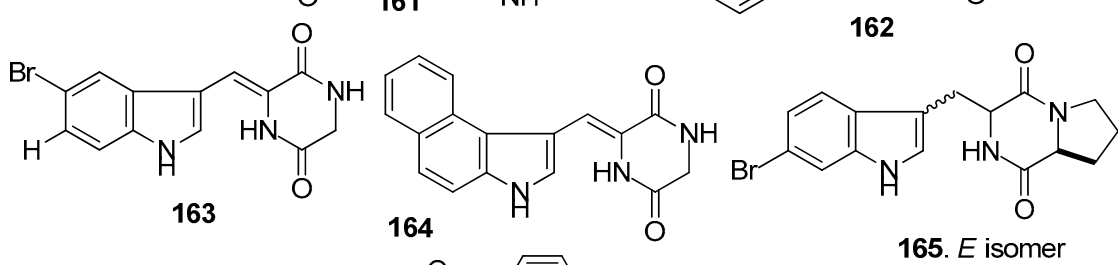<smiles>O=Cc1c[nH]c2cc(Br)ccc12</smiles>

166<smiles>N=C(N)NCCCC1NC(=O)C(C(O)(c2c[nH]c3cc(Br)ccc23)c2c[nH]c3c(=O)o[nH]c23)NC1=O</smiles>

Figure 14. Structures of AF indole alkaloids from sponges.

Other AF alkaloids (Figure 15): Aaptamine (168), isoaaptamine (169), and demethylated aaptamine (170) isolated from the sponge Aaptos aaptos showed AF activity against zebra mussel attachment [70]. A fraction of the acetone extract of the sponge Haliclona exigua was rich in bis-1-oxaquinolizidine alkaloid (171), exhibiting significant AF activity against the growths of seven fouling bacterial strains and against the settlement of B. amphitrite larvae [71].<smiles>[R2]Oc1cc2ccnc3c2c(c1O[R])N([R3])C=C3</smiles>

$$
\begin{aligned}
& \text { 168. } R_{1}=C_{3}, R_{2}=C_{3}, R_{3}=H \\
& \text { 169. } R_{1}=C_{3}, R_{2}=C_{3}, R_{3}=H \\
& \text { 170. } R_{1}=H, R_{2}=H, R_{3}=H
\end{aligned}
$$

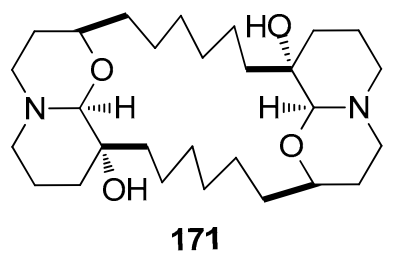

171

Figure 15. Structures of other kinds of AF alkaloids from sponges.

\subsection{Other Kinds of Compounds}

Besides the above characteristic terpenoids, alkaloids and steroids, there were many other kinds of AF compounds isolated from marine invertebrates, such as polyacetylenes, butenolides, phenol derivatives, and peptides.

AF polyacetylene derivatives (Figure 16): Callytetrayne (172), callypentayne (173), callytriols A-E (174-178) and callyspongins A-B (179-180) from the sponge Callyspongia truncate showed potent metamorphosis-inducing activity towards the ascidian Halocynthia roretzi larvae with $\mathrm{ED}_{100}$ values of $0.13-1.3 \mu \mathrm{g} / \mathrm{mL}$, and $\mathbf{1 7 4}-\mathbf{1 8 0}$ also showed AF activity against B. amphitrite larvae with $\mathrm{ED}_{50}$ values of $0.24-4.5 \mu \mathrm{g} / \mathrm{mL}[72]$. 


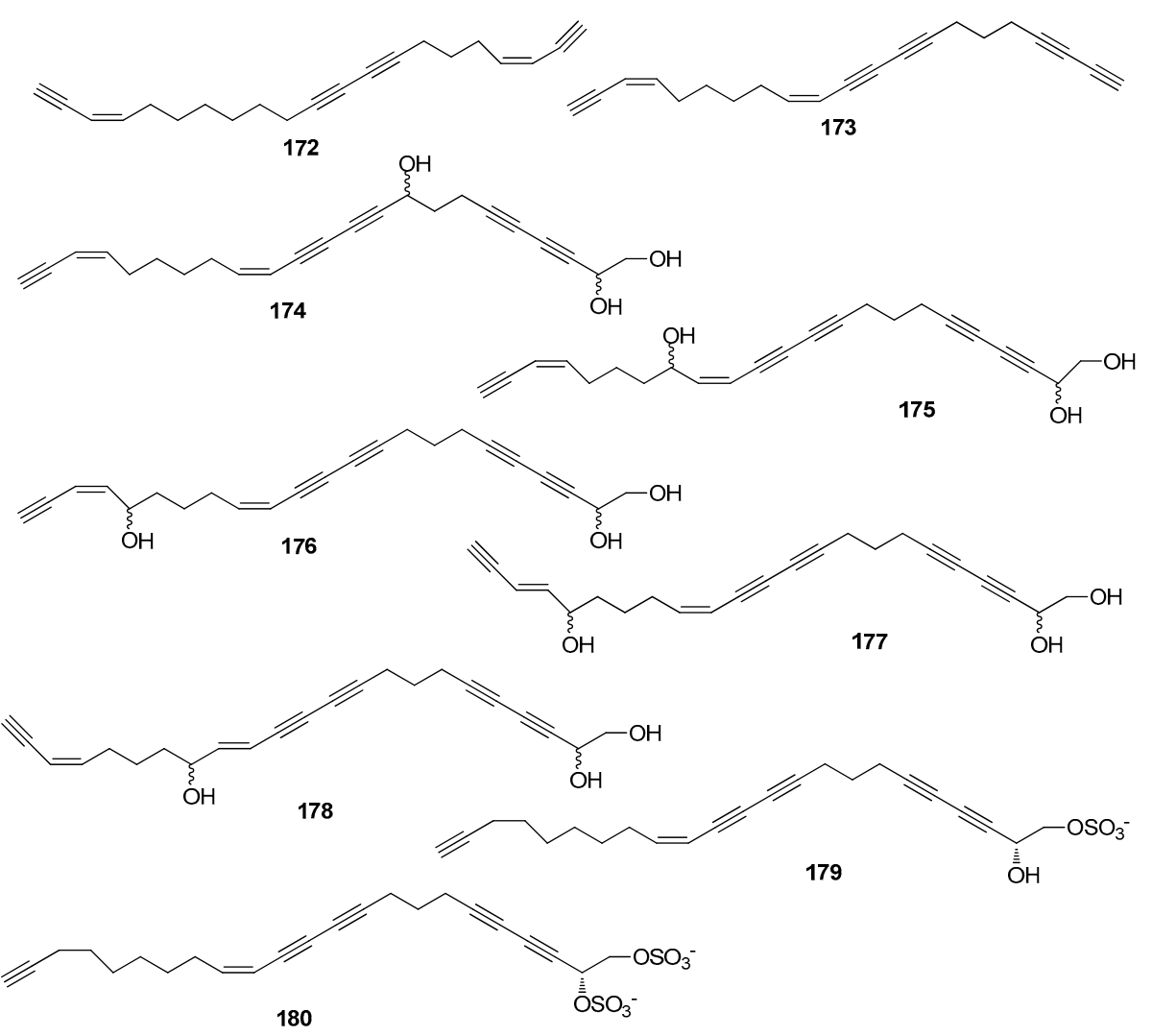

Figure 16. Structures of AF polyacetylene derivatives from sponges.

AF butenolides (Figure 17): Sinularones G-I (181-183) from a soft coral Sinularia sp. showed moderate AF activity against the barnacle $B$. amphitrite [32]. Butenolide (5R)-5-(1-ethoxypropyl) -5-hydroxy-3,4-dimethylfuran-2(5H)-one (184) as a pair of inseparable epimers, along with (S)-5-hydroxy -3,4-dimethyl-5-propylfuran-2(5H)-one (185) and (S)-5-hydroxy-3,4-dimethyl-5pentylfuran-2(5H)-one (186) were obtained from the gorgonian $S$. suberosa. Compounds 184-186 exhibited moderate AF activity against the settlement of $B$. amphitrite larvae [73]. The structure-activity relationship indicated that $\alpha, \beta$-unsaturated 2,3-dimethyl- $\gamma$-lactone was a functional unit for the antilarval activity.<smiles>CCOC(=O)CCC1(O)OC(=O)C(C)=C1C</smiles><smiles>CCOC(=O)CCCCCCCCCCCC1(O)OC(=O)C(C)=C1C</smiles><smiles>CCOC1(CCC(=O)OC)OC(=O)C(C)=C1C</smiles><smiles>CCOC(CC)C1(O)OC(=O)C(C)=C1C</smiles><smiles>CCCCC1(O)OC(=O)C(C)=C1C</smiles>

Figure 17. Structures of AF polyacetylene derivatives from sponges.

AF brominated phenol derivatives (Figure 18): Brominated diphenyl ethers are the characteristic secondary metabolites of the genus Dyside. It was believed that this type of compound was biosynthesised by the symbiotic cyanobacteria of the sponge. Five polybrominated diphenyl ethers including 187 from a sponge Callyspongia sp., 188 from Dysidea granulosa, and 189-191 from D. herbacea 
were investigated against several taxa of prominent fouling organisms including marine bacteria, the diatom A. coffeaeformis, the barnacle B. amphitrite and the mussel Mytilus edulis. All of these compounds exhibited significant antibacterial and AF activity. Compound 187 was the strongest in all the bioassays with non-toxicity. It inhibited the growth of all of the tested bacterial strains with MIC $\frac{1}{4} 0.02-1.52 \mu \mathrm{M}$, and inhibited the larval settlement of $A$. coffeaeformis, $B$. amphitrite and M. edulis larvae with $\mathrm{EC}_{50}$ values of $0.24,0.66$ and $1.26 \mu \mathrm{M}$, respectively [74].

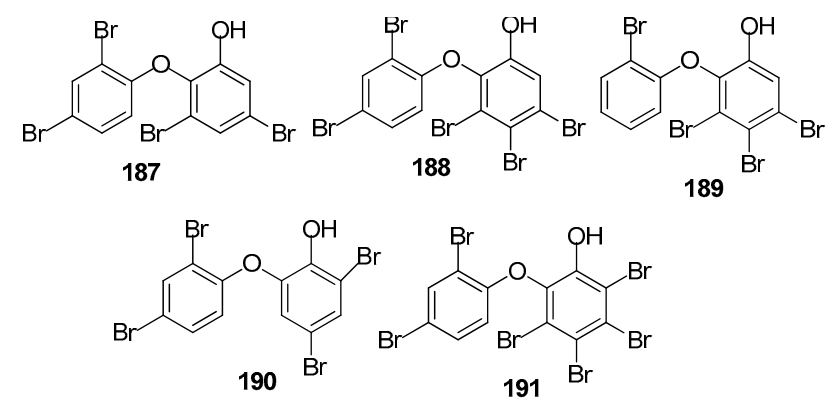

Figure 18. Structures of AF brominated phenol derivatives from sponges.

Other AF compounds (Figure 19): Four avermectin derivatives, avermectins $B_{1 c}$ and $B_{1 e}$ (192 and 193), avermectin $B_{2 a}(194)$ and ivermectin $A_{1 a}$ (195) from the gorgonian Anthogorgia caerulea exhibited potent antilarval activity towards B. amphitrite larvae with low-toxicity [75]. 1-O-palmityl-sn-glycero-3-phosphocholine (196) from the sponge Crella incrustans showed strong inhibition against the settlement of $B$. amphitrite larvae [76]. Two novel disulfide-containing peptides, barrettides A (197) and B (198) from the sponge Geodia barrette showed significant antilarval activity against the settlement of $B$. improvises larvae at concentrations of 0.6 and $6 \mu \mathrm{M}$, respectively [77].
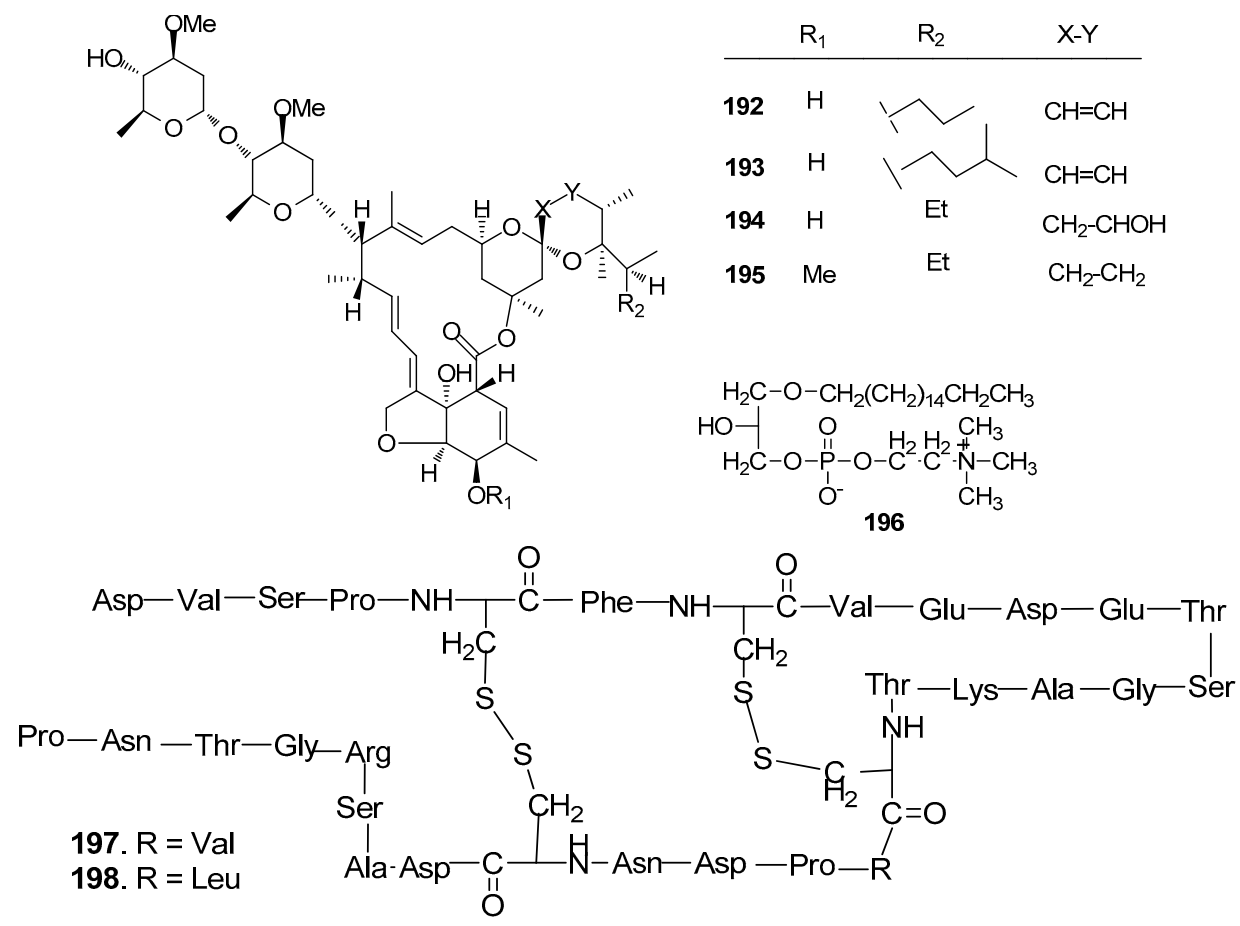

Figure 19. Structures of other kinds of AF compounds from sponges and corals. 


\section{Conclusions}

Totally, over 198 AF compounds have been obtained from marine invertebrates, especially, sponges, gorgonian and soft corals. These compounds covered isocyanoterpenoids, sesquiterpenes, diterpenes, sesterterpenes, triterpenoids, alkaloids (including bromotyrosine-derived, pyrrole-derived, pyridine-derived and indole-derived compounds), steroids, polyacetylenes, butenolides, peptides, and phenol derivatives, which played important chemical defense roles in the marine invertebrates. In here, the AF activities of 198 compounds towards microfouling and macrofouling were summarized in Table 1. It is thought that AF compounds have medium to high bioactivity with a threshold of $\mathrm{EC}_{50}<15 \mu \mathrm{g} / \mathrm{mL}$, and $\mathrm{AF}$ compounds having high $\mathrm{LC}_{50} / \mathrm{EC}_{50}$ ratios $(>15)$ are potentially good candidate antifoulants [14]. From Table 1, we can see that some of these compounds are potent antifoulants with low/non-toxicity, such as some of the isocyanoterpenoids, briarane-type diterpenoids, cembrane-type diterpenoids, and indole alkaloids. However, little was known about their mode of actions and AF activities in fields, because of the serious problems of the supplies from these marine invertebrates, which restricted the development of these potent AF compounds in antifouling paints. Although some studies about the total synthesis of several isocyanoterpenoids, briarane-type diterpenoids, and cembrane-type diterpenoids have been done, too many steps of these synthetic routes with low yields limited their applications. To overcome the problems, more studies about the organic syntheses of these potent AF compounds as models are needed. In addition, scientists have paid more attention to AF compounds from marine microorganisms, especially sponge-derived and gorgonian-derived microorganisms in recent years.

Table 1. AF activities of 1-198 towards microfouling (mainly by bacteria and diatoms) and macrofouling (mainly by B. amphitrite, B. albicostatus, B. improvises, B. neritina, M. edulis, P. viridis or H. roretzi).

\begin{tabular}{|c|c|}
\hline Compounds & AF Activity \\
\hline 6-9 & against $B$. amphitrite larvae, $\mathrm{EC}_{50}<0.5 \mu \mathrm{g} / \mathrm{mL}$ \\
\hline 10-21 & against $B$. amphitrite larvae, $\mathrm{EC}_{50}=1.43,0.72,1.48,1.16,0.53,0.74,1.85,0.92,0.69,0.27,1.37,0.41 \mu \mathrm{M}$ \\
\hline $22-23$ & effective in deterring the settlement of the diatom N. closterium \\
\hline 27-30 & against $B$. amphitrite larvae, $\mathrm{EC}_{50}=0.65,3.41,0.65,0.45 \mu \mathrm{g} / \mathrm{mL}$ \\
\hline 31-32 & against $B$. amphitrite larvae, $\mathrm{EC}_{50}=2.5,2.8 \mu \mathrm{g} / \mathrm{mL}$ \\
\hline 33-34 & significant antilarval activity and toxicity towards B. amphitrite larvae \\
\hline $35-37$ & $\begin{array}{l}\text { toxicity against the diatom } N \text {. closterium with } \mathrm{EC}_{50}=5.24,6.72,3.52 \mu \mathrm{M} \text {, and against } B \text {. neritina larvae } \\
\text { with } \mathrm{EC}_{50}=1.59,7.41,1.22 \mu \mathrm{M}\end{array}$ \\
\hline 44 & strongly deter fouling by invertebrates and algae \\
\hline $45-48$ & against $B$. amphitrite larvae, $\mathrm{EC}_{50}<7.0 \mu \mathrm{g} / \mathrm{mL}$ \\
\hline 49 & against $B$. amphitrite larvae, $\mathrm{EC}_{50}=0.0335 \mu \mathrm{g} / \mathrm{mL}$ \\
\hline 50 & against $B$. amphitrite larvae, $\mathrm{EC}_{50}=1.2 \mu \mathrm{g} / \mathrm{mL}$; against $B$. neritina larvae, $\mathrm{EC}_{50}=3.2 \mu \mathrm{g} / \mathrm{mL}$ \\
\hline 51-52 & against $B$. amphitrite larvae, $\mathrm{EC}_{50}=13.86,23.50 \mu \mathrm{g} / \mathrm{mL}$ \\
\hline 53-54 & against $B$. amphitrite larvae, $\mathrm{EC}_{50}=14.5,16.7 \mu \mathrm{M}$ \\
\hline $55-64$ & against $B$. amphitrite larvae, $\mathrm{EC}_{50}=4.1,1.82,6.3,7.6,4.6,1.2,5.6,0.79,2.0,0.2 \mu \mathrm{g} / \mathrm{mL}$ \\
\hline 65-78 & $\begin{array}{l}\text { against } B . \text { amphitrite larvae, } \mathrm{EC}_{50}=0.004,0.34,2.65,1.61,3.77,21.06,0.004,0.14,1.47,0.51,0.004,0.005 \text {, } \\
2.82,0.447 \mu \mathrm{g} / \mathrm{mL}\end{array}$ \\
\hline
\end{tabular}


Table 1. Cont.

\begin{tabular}{|c|c|}
\hline Compounds & AF Activity \\
\hline 90 & against $B$. amphitrite larvae, $\mathrm{EC}_{50}=9.02 \mu \mathrm{g} / \mathrm{mL}, \mathrm{LC}_{50}=36 \mu \mathrm{g} / \mathrm{mL}$ \\
\hline 91 & against $B$. amphitrite larvae, $\mathrm{EC}_{50}=19 \mathrm{ng} / \mathrm{mL}$ \\
\hline 92-95 & exhibited inhibition of biofilm maturation of P. aeruginosa, V. harveyi, and S. aureus \\
\hline 96-98 & showed bacterial biofilm inhibition at lower concentrations \\
\hline 99-100 & against $B$. amphitrite larvae, $\mathrm{EC}_{50}=5.65,14.03 \mu \mathrm{g} / \mathrm{mL}$ \\
\hline 101-102 & against $B$. amphitrite larvae, $\mathrm{EC}_{50}=4.86,4.57 \mu \mathrm{g} / \mathrm{mL}$; against $B$. neritina larvae, $\mathrm{EC}_{50}=12.34,13.48 \mu \mathrm{g} / \mathrm{mL}$ \\
\hline 103-104 & against B. amphitrite larvae, $\mathrm{ED}_{50}=4.32,2.12 \mu \mathrm{g} / \mathrm{mL}, \mathrm{LD}_{50}>50 \mu \mathrm{g} / \mathrm{mL}$ \\
\hline 105-108 & against $B$. amphitrite larvae, $\mathrm{EC}_{50}=2.25,1.75,8.13,7.50 \mu \mathrm{g} / \mathrm{mL}$ \\
\hline 109 & against B. amphitrite larvae, $\mathrm{EC}_{50}$ values ranging $0.02-0.2 \mu \mathrm{g} / \mathrm{mL}$ for 109 and renillafoulins $\mathrm{B}-\mathrm{C}$ \\
\hline 110 & inhibited the settlement of the tube worm $P$. californica at $10 \mu \mathrm{g} / \mathrm{mL}$ \\
\hline 111-112 & against $B$. amphitrite larvae, $\mathrm{EC}_{50}=4.0,2.9 \mu \mathrm{g} / \mathrm{mL}$ \\
\hline 113-115 & against $B$. albicostatus larvae, $\mathrm{EC}_{50}=8.2,23.5,31.6 \mu \mathrm{g} / \mathrm{mL}$ \\
\hline 116-117 & inhibited the growth of Pseudoalteromonas and Polaribacter bacterial species \\
\hline 118-120 & against $B$. neritina with $\mathrm{EC}_{50}=6.25,7.8 \mu \mathrm{g} / \mathrm{mL}, \mathrm{LD}_{50}>250 \mu \mathrm{g} / \mathrm{mL}$ \\
\hline 121 & against $B$. neritina larvae, $\mathrm{EC}_{50}=4.8 \mu \mathrm{g} / \mathrm{mL}, \mathrm{LC}_{50}>100 \mu \mathrm{g} / \mathrm{mL}$ \\
\hline 122-125 & against $B$. amphitrite larvae, $\mathrm{EC}_{50}=2.5,7.91,7.31,0.81 \mu \mathrm{g} / \mathrm{mL}$ \\
\hline 126 & against $B$. amphitrite larvae, $\mathrm{EC}_{50}=16.7 \mu \mathrm{g} / \mathrm{mL}$; against $B$. neritina larvae, $\mathrm{EC}_{50}=13.0 \mu \mathrm{g} / \mathrm{mL}$ \\
\hline 127 & against $B$. amphitrite larvae, $\mathrm{EC}_{50}=2.5 \mu \mathrm{g} / \mathrm{mL}, \mathrm{LC}_{50}>25.0 \mu \mathrm{g} / \mathrm{mL}$ \\
\hline 128-129 & against $B$. amphitrite larvae, $\mathrm{EC}_{50}=5.3,14.5 \mu \mathrm{g} / \mathrm{mL}$ \\
\hline 130-131 & against $B$. amphitrite larvae, $\mathrm{EC}_{50}=2.2 \mu \mathrm{g} / \mathrm{mL}$ \\
\hline $132-133$ & against $B$. amphitrite larvae, $\mathrm{EC}_{50}=$ from 10.0 to $50.0 \mu \mathrm{g} / \mathrm{mL}$ \\
\hline 134-135 & against $B$. amphitrite larvae, $\mathrm{EC}_{50}=5.0,4.3 \mu \mathrm{g} / \mathrm{mL}$ \\
\hline 136-139 & against $B$. amphitrite larvae, $\mathrm{ED}_{50}=$ from 0.10 to $8.0 \mu \mathrm{g} / \mathrm{mL}$ \\
\hline 140-145 & inhibited B. amphitrite larval settlement at 1 or $10 \mu \mathrm{M}$ \\
\hline 146 & promoted larval metamorphosis of the ascidian C. savignyi at a concentration of $2.5 \mu \mathrm{g} / \mathrm{mL}$ \\
\hline 147-148 & inhibited the larval metamorphosis of $B$. amphitrite larvae, $\mathrm{ED}_{50}=19,15 \mu \mathrm{g} / \mathrm{mL}$ \\
\hline 149 & against $B$. amphitrite larvae, $\mathrm{EC}_{50}=8.0 \mu \mathrm{g} / \mathrm{mL}$ \\
\hline 150-151 & $\begin{array}{l}\text { against the green mussel P. viridis }\left(\mathrm{EC}_{50}=31.77,138.18 \mu \mathrm{g} / \mathrm{mL}\right) \text {, the bryozoan } B . \text { neritina }\left(\mathrm{EC}_{50}=3.43,8.17\right. \\
\mu \mathrm{g} / \mathrm{mL}) \text { and the green alga U. prolifera }\left(\mathrm{EC}_{50}=8.31,0.67 \mu \mathrm{g} / \mathrm{mL}\right)\end{array}$ \\
\hline 152 & inhibited bacterial attachment towards Pseudomonas with an $\mathrm{IC}_{50}=0.73 \mu \mathrm{M}$ \\
\hline 153-157 & against $B$. amphitrite larvae, $\mathrm{EC}_{50}=2.22,3.6,0.28,2.81,0.53, \mu \mathrm{g} / \mathrm{mL}$ \\
\hline 158-159 & anti-adhesion activity against one marine bacterial strain \\
\hline 160-161 & against $B$. improvises cyprids, $\mathrm{EC}_{50}=0.9,7.9 \mu \mathrm{M}$ \\
\hline $162-166$ & against $B$. improvises cyprids, $\mathrm{EC}_{50}=0.034,5.8,1.5,2.4,6.7 \mu \mathrm{M}$ \\
\hline 167 & against $B$. improvises cyprids, $\mathrm{EC}_{50}=15 \mathrm{nM}$ \\
\hline 168-170 & against zebra mussel attachment with $\mathrm{EC}_{50}=24.2,11.6,18.6 \mu \mathrm{M}$ \\
\hline 171 & against cyprids of B. amphitrite $\left(\mathrm{EC}_{50}=6.6 \mu \mathrm{g} / \mathrm{mL}, \mathrm{LC}_{50}=18 \mu \mathrm{g} / \mathrm{mL}\right)$ and seven strains of fouling bacteria \\
\hline 172-180 & $\begin{array}{l}\text { against } B \text {. amphitrite larvae with } \mathrm{ED}_{50}=0.24-4.5 \mu \mathrm{g} / \mathrm{mL} \text { for } \mathbf{1 7 4}-\mathbf{1 8 0} \text {; and metamorphosis-inducing } \\
\text { activity in the ascidian } H \text {. roretzi larvae with } \mathrm{ED}_{100}=0.13-1.3 \mu \mathrm{g} / \mathrm{mL} \text { for } \mathbf{1 7 2}-\mathbf{1 8 0} \text {. }\end{array}$ \\
\hline 181-183 & $\mathrm{EC}_{50}=18.65,21.39,12.58 \mu \mathrm{g} / \mathrm{mL}$ \\
\hline 184-186 & against $B$. amphitrite larvae, $\mathrm{EC}_{50}=13.5,16.3,12.8 \mu \mathrm{g} / \mathrm{mL}$ \\
\hline 187-191 & $\begin{array}{l}\text { significant antibacterial and antifouling activity towards marine bacteria, A. coffeaeformis, B. amphitrite and } \\
\text { M. edulis }\end{array}$ \\
\hline 192-195 & against B. amphitrite larvae, $\mathrm{ED}_{50}=15.81,6.25,4.81,7.78 \mu \mathrm{g} / \mathrm{mL}, \mathrm{LD}_{50}>200 \mu \mathrm{g} / \mathrm{mL}$ \\
\hline 196 & strong inhibition against the settlement of B. amphitrite larvae \\
\hline 197-198 & 197 inhibited the settlement of $B$. improvises larvae at both 0.6 and $6 \mu \mathrm{M}$, whereas 198 only at $6 \mu \mathrm{M}$ \\
\hline
\end{tabular}


Acknowledgments: We are grateful for the financial support provided by the Natural Science Foundation of China (41376160 and 81673326), Regional Innovation Demonstration Project of Guangdong Province Marine Economic Development (GD2012-D01-002), and the Strategic Leading Special Science and Technology Program of Chinese Academy of Sciences (XDA100304002).

Author Contributions: Shu-Hua Qi designed and writed the paper; Xuan Ma looked up part of the references and drew part of the chemical structures.

Conflicts of Interest: The authors declare no conflict of interest.

\section{References}

1. Yebra, D.M.; Kiil, S.; Dam-Johansen, K. Antifouling technology-past, present and future steps towards efficient and environmentally friendly antifouling coatings. Prog. Org. Coat. 2004, 50, 75-104. [CrossRef]

2. Qian, P.Y.; Xu, Y.; Fusetani, N. Natural products as antifouling compounds: Recent progress and future perspectives. Biofouling 2010, 26, 223-234. [CrossRef] [PubMed]

3. Omae, I. Organotin antifouling paints and their alternatives. Appl. Organomet. Chem. 2003, 17, 81-105. [CrossRef]

4. Rittschof, D. Natural product antifoulants and coatings development. In Marine Chemical Ecology; Clintock, J.B., Baker, B.J., Eds.; Taylor \& Francis: Abingdon, UK, 2001; pp. 543-566.

5. Faÿ, F.; Linossier, I.; Peron, J.J.; Langlois, V.; Vallée-Rehel, K. Antifouling activity of marine paints: Study of erosion. Prog. Org. Coat. 2007, 60, 194-206. [CrossRef]

6. Fusetani, N.; Clare, A.S. (Eds.) Antifouling Compounds; Springer: Berlin, Germany, 2006.

7. Hellio, C.; Yebra, D. (Eds.) Advances in Marine Antifouling Coatings and Technologies; Woodhead Publishing: Cambridge, UK, 2010.

8. Pawilk, J.R. Marine invertebrate chemical defences. Chem. Rev. 1993, 93, 1911-1922. [CrossRef]

9. Omae, I. General Aspects of Natural Products Antifoulants in the Environment. Handb. Environ. Chem. 2006, $5,227-262$.

10. Raveendran, T.V.; Mol, V.P.L. Natural product antifoulants. Curr. Sci. 2009, 97, 508-520.

11. Marechal, J.P.; Hellio, C. Challenges for the development of new non-toxic antifouling solutions. Int. J. Mol. Sci. 2009, 10, 4623-4637. [CrossRef] [PubMed]

12. Fusetani, N. Biofouling and antifouling. Nat. Prod. Rep. 2004, 21, 94-104. [CrossRef] [PubMed]

13. Fusetani, N. Antifouling marine natural products. Nat. Prod. Rep. 2011, 28, 400-410. [CrossRef] [PubMed]

14. Qian, P.Y.; Li, Z.; Xu, Y.; Li, Y.; Fusetani, N. Mini-review: Marine natural products and their synthetic analogs as antifouling compounds: 2009-2014. Biofouling 2015, 31, 101-122. [CrossRef] [PubMed]

15. Okino, T.; Yoshimura, E.; Hirota, H.; Fusetani, N. Antifouling kalihinenes from the marine sponge Acanthella cavernosa. Tetrahedron Lett. 1996, 36, 8637-8640. [CrossRef]

16. Okino, T.; Yoshimura, E.; Hirota, H.; Fusetani, N. New antifouling kalihipyrans from the marine sponge Acanthella cavernosa. J. Nat. Prod. 1996, 59, 1081-1083. [CrossRef]

17. Hirota, H.; Tomono, Y.; Fusetani, N. Terpenoids with antifouling activity against barnacle larvae from the marine sponge Acanthella cavernosa. Tetrahedron 1996, 52, 2359-2368. [CrossRef]

18. Okino, T.; Yoshimura, E.; Hirota, H.; Fusetani, N. New antifouling sesquiterpenes from four nudibranchs of the family Phyllidiidae. Tetrahedron 1996, 52, 9447-9454. [CrossRef]

19. Xu, Y.; Li, N.; Jiao, W.H.; Qi, S.H.; Lin, H.W. Antifouling and cytotoxic constituents from the South China Sea sponge Acanthella cavernosa. Tetrahedron 2012, 68, 2876-2883. [CrossRef]

20. Wright, A.M.A.D.; Robertson, M.J.; MacGregor, K.A.; Gordonb, C.P.; Guentherc, J. Anti-malarial, anti-algal, anti-tubercular, anti-bacterial, anti-photosynthetic, and anti-fouling activity of diterpene and diterpene isonitriles from the tropical marine sponge Cymbastela hooperi. Org. Biomol. Chem. 2011, 9, 400-407. [CrossRef] [PubMed]

21. Hirota, H.; Okino, T.; Yoshimura, E.; Fusetani, N. Five new antifouling sesquiterpenes from two marine sponges of the genus Axinyssa and the nudibranch Phyllidia pustulosa. Tetrahedron 1998, 54, 13971-13980. [CrossRef] 
22. Tsoukatou, M.; Maréchal, J.P.; Hellio, C.; Novaković, I.; Tufegdzic, S.; Sladić, D.; Gašić, M.J.; Clare, A.S.; Vagias, C.; Roussis, V. Evaluation of the activity of the sponge metabolites avarol and avarone and their synthetic derivatives against fouling micro- and macroorganisms. Molecules 2007, 12, 1022-1034. [CrossRef] [PubMed]

23. Tsukamoto, S.; Kato, H.; Hirota, H.; Fusetani, N. Antifouling terpenes and steroids against barnacle larvae from marine sponges. Biofouling 1997, 11, 283-291. [CrossRef]

24. Hertiani, T.; Edrada-Ebel, R.; Ortlepp, S.; Van Soest, R.W.; De Voogd, N.J.; Wray, V.; Hentschel, U.; Kozytska, S.; Müller, W.E.; Proksch, P. From anti-fouling to biofilm inhibition: New cytotoxic secondary metabolites from two Indonesian Agelas sponges. Bioorg. Med. Chem. 2010, 18, 1297-1311. [CrossRef] [PubMed]

25. Stewart, M.; Depree, C.; Thompson, K.J. Antifouling sesterterpenes from the New Zealand marine sponge Semitaspongia bactriana. Nat. Prod. Commun. 2009, 4, 331-336. [PubMed]

26. Hellio, C.; Tsoukatou, M.; Maréchal, J.P.; Aldred, N.; Beaupoil, C.; Clare, A.S.; Vagias, C.; Roussis, V. Inhibitory effects of mediterranean sponge extracts and metabolites on larval settlement of the barnacle Balanus amphitrite. Mar. Biotechnol. 2005, 7, 297-305. [CrossRef] [PubMed]

27. Skindersoe, M.E.; Ettinger-Epstein, P.; Rasmussen, T.B.; Bjarnsholt, T.; de Nys, R.; Givskov, M. Quorum sensing antagonism from marine organisms. Mar. Biotechnol. 2008, 10, 56-63. [CrossRef] [PubMed]

28. Jaspars, M.; Crews, P. A triterpene tetrasaccharide, formoside, from the Caribbean Choristida sponge Erylus formosus. Tetrahedron Lett. 1994, 35, 7501-7504. [CrossRef]

29. Chen, D.; Yu, S.; Van Ofwegen, L.; Proksch, P.; Lin, W. Anthogorgienes A-O, new guaiazulene-derived terpenoids from a Chinese gorgonian Anthogorgia species, and their antifouling and antibiotic activities. J. Agric. Food Chem. 2012, 60, 112-123. [CrossRef] [PubMed]

30. Raveendran, T.V.; Limna, M.V.P.; Parameswaran, P.S. Natural product antifoulants from the octocorals of Indian waters. Int. Biodeter. Biodegrad. 2011, 65, 265-268. [CrossRef]

31. Qi, S.H.; Zhang, S.; Yang, L.H.; Qian, P.Y. Antifouling and antibacterial compounds from the gorgonians Subergorgia suberosa and Scripearia gracillis. Nat. Prod. Res. 2008, 22, 154-166. [CrossRef] [PubMed]

32. Shi, H.; Yu, S.; Liu, D.; van Ofwegen, L.; Proksch, P.; Lin, W. Sinularones A-I, new cyclopentenone and butenolide derivatives from a marine soft coral Sinularia sp. and their antifouling activity. Mar. Drugs 2012, 10, 1331-1344. [CrossRef] [PubMed]

33. Yang, J.; Zhang, S.; Qi, S.H.; Pan, J.; Qiu, Y.; Tao, S.; Yin, H.; Li, Q. Briarane-type diterpenoids from the China gorgonian coral Subergorgia reticulata. Biochem. Syst. Ecol. 2007, 35, 770-773. [CrossRef]

34. Sun, J.F.; Han, Z.; Zhou, X.F.; Yang, B.; Lin, X.; Liu, J.; Peng, Y.; Yang, X.W.; Liu, Y.H. Antifouling briarane type diterpenoids from South China Sea gorgonians Dichotella gemmacea. Tetrahedron 2013, 69, 871-880. [CrossRef]

35. Qi, S.H.; Zhang, S.; Qian, P.Y.; Xiao, Z.H.; Li, M.Y. Ten new antifouling briarane diterpenoids from the South China Sea gorgonian Junceella juncea. Tetrahedron 2006, 62, 9123-9130. [CrossRef]

36. Qi, S.H.; Zhang, S.; Qian, P.Y.; Xu, H.H. Antifeedant and abtifouling briaranes from the South China Sea gorgonian Junceella juncea. Chem. Nat. Comp. 2009, 45, 49-54. [CrossRef]

37. Lei, H.; Sun, J.; Han, Z.; Zhou, X.F.; Yang, B.; Liu, Y. Fragilisinins A-L, new briarane-type diterpenoids from gorgonian Junceella fragilis. RSC Adv. 2014, 4, 5261-5271. [CrossRef]

38. Kong, W.W.; Shao, C.L.; Wang, C.Y. Diterpenoids and steroids from gorgonian Subergorgia mollis. Chem. Nat. Comp. 2012, 48, 512-515. [CrossRef]

39. Lai, D.; Liu, D.; Deng, Z.; Van Ofwegen, L.; Proksch, P.; Lin, W. Antifouling eunicellin-type diterpenoids from the gorgonian Astrogorgia sp. J. Nat.Prod. 2012, 75, 1595-1602. [CrossRef] [PubMed]

40. Mol, V.P.L.; Raveendran, T.V.; Parameswaran, P.S.; Kunnath, R.J.; Rajamohanan, P.R. (-)-6 $\alpha$-Hydroxy polyanthellin A-A novel antifouling diterpenoid from the Indian soft coral Cladiella krempfi (Hickson). Can. J. Chem. 2011, 89, 57-60. [CrossRef]

41. Gerhart, D.J.; Coll, J.C. Pukalide, a widely distributed octocoral diterpenoid, induces vomiting in fish. J. Chem. Ecol. 1993, 19, 2697-2704. [CrossRef] [PubMed]

42. Tello, E.; Castellanos, L.; Arevalo-Ferro, C.; Rodríguez, J.; Jiménez, C.; Duque, C. Absolute stereochemistry of antifouling cembranoid epimers at C-8 from the Caribbean octocoral Pseudoplexaura flagellosa. Revised structures of plexaurolones. Tetrahedron 2011, 67, 9112-9121. [CrossRef]

43. Tello, E.; Castellanos, L.; Arevalo-Ferro, C.; Duque, C. Disruption in quorum-sensing systems and bacterial biofilm inhibition by cembranoid diterpenes isolated from the octocoral Eunicea knighti. J. Nat. Prod. 2012, 75, 1637-1642. [CrossRef] [PubMed] 
44. Lai, D.; Li, Y.; Xu, M.; Deng, Z.; Ofwegend, L.; Qian, P.; Proksche, P.; Lin, W. Sinulariols A-S, 19-oxygenated cembranoids from the Chinese soft coral Sinularia rigida. Tetrahedron 2011, 7, 6018-6029. [CrossRef]

45. Lai, D.; Geng, Z.; Deng, Z.; Van Ofwegen, L.; Proksch, P.; Lin, W. Cembranoids from the soft coral Sinularia rigida with antifouling activities. J. Agric. Food Chem. 2013, 61, 4585-4592. [CrossRef] [PubMed]

46. Shen, S.; Zhu, H.; Chen, D.; Liu, D.; Ofwegenc, L.; Prokschd, P.; Lin, W. Pavidolides A-E, new cembranoids from the soft coral Sinularia pavida. Tetrahedron Lett. 2012, 53, 5759-5762. [CrossRef]

47. Wang, C.Y.; Chen, A.N.; Shao, C.L.; Li, L.; Xu, Y.; Qian, P.Y. Chemical constituents of soft coral Sarcophyton infundibuliforme from the South China Sea. Biochem. System. Ecol. 2011, 39, 853-856. [CrossRef]

48. Keifer, P.A.; Rinehart, J.K.L.; Hooper, I.R. Renillafoulins, antifouling diterpenes from the sea pansy Renilla reniformis (Octocorallia). J. Org. Chem. 1986, 51, 4450-4454. [CrossRef]

49. Rittschof, D.; Hooper, I.R.; Costlow, J.D. Barnacle settlement inhibitors from sea pansies, Renilla reniformis. Bull. Mar. Sci. 1986, 39, 376-382.

50. Manker, D.C.; John, F.D. Investigation of the role of diterpenes produced by marine pulmonates Trimusculus reticulatus and T. conica. J. Chem. Ecol. 1996, 22, 23-35. [CrossRef] [PubMed]

51. Qiu, Y.; Deng, Z.W.; Xu, M.; Li, Q.; Lin, W.H. New A-nor steroids and their antifouling activity from the Chinese marine sponge Acanthella cavernosa. Steroids 2008, 73, 1500-1504. [CrossRef] [PubMed]

52. Nguyen, X.C.; Longeon, A.; Pham, V.C.; Bourguet-Kondracki, M. Antifouling 26,27-cyclosterols from the Vietnamese marine sponge Xestospongia testudinaria. J. Nat. Prod. 2013, 76, 1313-1318. [CrossRef] [PubMed]

53. Qi, S.H.; Gao, C.H.; Qian, P.Y.; Zhang, S. Steroids from the South China Sea gorgonian Subergorgia suberosa. Nat. Prod. Commun. 2010, 5, 201-204. [PubMed]

54. Qi, S.H.; Miao, L.; Gao, C.H.; Xu, Y.; Zhang, S.; Qian, P.Y. New steroids and a new alkaloid from the gorgonian Isis minorbrachyblasta: Structures, cytotoxicity, and antilarval activity. Helv. Chim. Acta 2010, 93, 511-516. [CrossRef]

55. Zhang, J.; Li, L.C.; Wang, K.L.; Liao, X.J.; Deng, Z.; Xu, S.H. Pentacyclic hemiacetal sterol with antifouling and cytotoxic activities from the soft coral Nephthea sp. Bioorg. Med. Chem. Lett. 2013, 23, 1079-1082. [CrossRef] [PubMed]

56. Zhang, J.; Liang, Y.; Wang, K.L.; Liao, X.J.; Deng, Z.; Xu, S.H. Antifouling steroids from the South China Sea gorgonian coral Subergorgia suberosa. Steroids 2014, 79, 1-6. [CrossRef] [PubMed]

57. Zhou, Y.M.; Chen, M.; Fu, X.M.; Fang, Y.C.; Wang, C.Y. Two new eunicellin-based diterpenoids from the South China Sea gorgonian Muricella sibogae Nutting. Nat. Prod. Res. 2014, 28, 1176-1181. [CrossRef] [PubMed]

58. Tsukamoto, S.; Kato, H.; Hirota, H.; Fusetani, N. Ceratinamides A and B: New antifouling dibromotyrosine derivatives from the marine sponge Pseudoceratina purpurea. Terrahedron 1996, 52, 8181-8186. [CrossRef]

59. Tsukamoto, S.; Kato, H.; Hirota, H.; Fusetani, N. Ceratinamine: An unprecedented antifouling cyanoformamide from the marine sponge Pseudoceratina purpurea. J. Org. Chem. 1996, 61, 2936-2937. [CrossRef] [PubMed]

60. Ortlepp, S.; Sjogren, M.; Dahlstrom, M.; Weber, H.; Ebel, R.; Edrada, R.; Thoms, C.; Schupp, P.; Bohlin, L.; Proksch, P. Antifouling activity of bromotyrosine-derived sponge metabolites and synthetic analogues. Mar. Biotechnol. 2007, 9, 776-785. [CrossRef] [PubMed]

61. Tsukamoto, H.K.S.; Hirota, H.; Fusetani, N. Mauritiamine, a new antifouling oroidin dimer from the marine sponge Agelas mauritiana. J. Nat. Prod. 1996, 59, 501-503. [CrossRef]

62. Tsukamoto, S.; Kato, H.; Hirota, H.; Fusetani, N. Pseudoceratidine: A new antifouling spermidine derivative from the marine sponge Pseudoceratina purpurea. Terrahedron Lett. 1996, 37, 1439-1440. [CrossRef]

63. Feng, D.; Qiu, Y.; Wang, W.; Wang, X.; Ouyang, P.; Ke, C. Antifouling activities of hymenialdisine and debromohymenialdisine from the sponge Axinella sp. Int. Biodeter. Biodegrad. 2013, 85, 359-364. [CrossRef]

64. Richards, J.J.; Melander, C. Controlling bacterial biofilms. Chembiochem 2009, 10, 2287-2294. [CrossRef] [PubMed]

65. Blihoghe, D.; Manzo, E.; Villela, A.; Cutignano, A.; Picariello, G.; Faimali, M.; Fontana, A. Evaluation of the antifouling properties of 3-alyklpyridine compounds. Biofouling 2011, 27, 99-109. [CrossRef] [PubMed]

66. Penez, N.; Culioli, G.; Perez, T.; Briand, J.F.; Thomas, O.P.; Blache, Y. Antifouling properties of simple indole and purine alkaloids from the Mediterranean gorgonian Paramuricea clavata. J. Nat. Prod. 2011, 74, 2304-2308. [CrossRef] [PubMed] 
67. Sjögren, M.; Göransson, U.; Johnson, A.; Dahlström, M.; Andersson, R.; Bergman, J.; Jonsson, P.R.; Bohlin, L. Antifouling activity of brominated cyclopeptides from the marine sponge Geodia barretti. J. Nat. Prod. 2004, 67, 368-372. [CrossRef] [PubMed]

68. Sjogren, M.; Johnson, A.L.; Hedner, E.; Dahlström, M.; Göransson, U.; Shirani, H.; Bergman, J.; Jonsson, P.R.; Bohlin, L. Antifouling activity of synthesized peptide analogs of the sponge metabolite barettin. Peptides 2006, 27, 2058-2064. [CrossRef] [PubMed]

69. Hedner, E.; Sjögren, M.; Hodzic, S.; Andersson, R.; Göransson, U.; Jonsson, P.R.; Bohlin, L. Antifouling activity of a dibrominated cyclopeptide from the marine sponge Geodia barretti. J. Nat. Prod. 2008, 71, 330-333. [CrossRef] [PubMed]

70. Diers, J.A.; Bowling, J.J.; Duke, S.O.; Wahyuono, S.; Kelly, M.; Hamann, M.T. Zebra mussel antifouling activity of the marine natural product aaptamine and analogs. Mar. Biotechnol. 2006, 8, 366-372. [CrossRef] [PubMed]

71. Limna, M.V.P.; Raveendran, T.V.; Parameswaran, P.S. Antifouling activity exhibited by secondary metabolites of the marine sponge, Haliclona exigua (Kirkpatrick). Int. Biodeter. Biodegrad. 2009, 63, 67-72. [CrossRef]

72. Tsukamoto, S.; Kato, H.; Hirota, H.; Fusetani, N. Seven new polyacetylene derivatives, showing both potent metamorphosis-inducing activity in ascidian larvae and antifouling activity against barnacle larvae, from the marine sponge Callyspongia truncata. J. Nat. Prod. 1997, 60, 128-130. [CrossRef]

73. Zhang, J.; Liang, Y.; Liao, X.J.; Deng, Z.; Xu, S.H. Isolation of a new butenolide from the South China Sea gorgonian coral Subergorgia suberosa. Nat. Prod. Res. 2014, 28, 150-155. [CrossRef] [PubMed]

74. Ortlepp, S.; Pedpradap, S.; Dobretsov, S.; Proksch, P. Antifouling activity of sponge-derived polybrominated diphenyl ethers and synthetic analogues. Biofouling 2008, 24, 201-208. [CrossRef] [PubMed]

75. Gao, C.; Wang, Y.; Chen, Y.; He, B.; Zhang, R.; Xu, M.; Huang, R. Two new avermectin derivatives from the Beibu Gulf gorgonian Anthogorgia caerulea. Chem. Biodiver. 2014, 11, 812-818. [CrossRef] [PubMed]

76. Alan, J.; Butler, I.; Dunne, S.J. Antifouling activity of lyso-platelet-activating factor extracted from Australian sponge Crella incrustans. J. Chem. Ecol. 1996, 22, 2041-2060.

77. Carstens, B.B.; Rosengren, K.J.; Gunasekera, S.; Schempp, S.; Bohlin, L.; Dahlström, M.; Clark, R.J.; Göransson, U. Isolation, characterization, and synthesis of the barrettides: disulfide-containing peptides from the marine sponge Geodia barretti. J. Nat. Prod. 2015, 78, 1886-1893. [CrossRef] [PubMed] 